\title{
Human Insulin: History, Recent Advances, and Expression Systems for Mass Production
}

\author{
Jessica Alyas ${ }^{1}$, Ayesha Rafiq ${ }^{1}$, Horia Amir ${ }^{1}$, Safir Ullah Khan ${ }^{2}$, Tahira Sultana ${ }^{3}$, Amir Ali ${ }^{3}$, Asma Hameed ${ }^{3}$, \\ Ilyas Ahmad ${ }^{3}$, Abeer Kazmi ${ }^{4,5}$, , Tehmina Sajid ${ }^{6}$, Ayaz Ahmad7
}

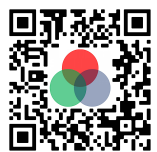

Use your smartphone to scan this QR code and download this article

${ }^{1}$ Department of Biotechnology, Kinnaird College for Women University, Lahore, Pakistan

${ }^{2}$ Department of Zoology, PMAS, Arid Agriculture University, Rawalpindi, Pakistan

${ }^{3}$ Department of Botany, PMAS, Arid Agriculture University, Rawalpindi, Pakistan

${ }^{4}$ Department of Biotechnology, Faculty of Chemical and Life Sciences, Abdul Wali Khan University Mardan (AWKUM), Mardan, Pakistan

Correspondence

Abeer Kazmi, Department of Biotechnology, Faculty of Chemical and Life Sciences, Abdul Wali Khan University Mardan (AWKUM), Mardan, Pakistan

Department of Genetics, Institute of Hydrobiology, University of Chinese Academy of Sciences (UCAS), Wuhan, PR China

Email: Abeer_Kazmi@yahoo.com History

- Received: Aug 12, 2021

- Accepted: Sep 19, 2021

- Published: Sep 30, 2021

DOI : 10.15419/bmrat.v8i9.692

\section{Check for updates}

\section{Copyright}

() Biomedpress. This is an openaccess article distributed under the terms of the Creative Commons Attribution 4.0 International license.

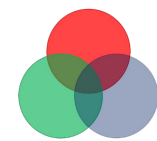

\section{INTRODUCTION}

An insulin shortage or the absence of proper cell responses to the available insulin can lead to diabetes mellitus ${ }^{1,2}$. With diabetes and obesity reaching proportions of an epidemic in the developing world, insulin resistance and its associated symptoms are becoming more common ${ }^{3}$. Human insulin is a peptide hormone with a molecular mass of 5808 Da produced by the beta cells of the islets of Langerhans of the pancreas, and it is responsible for regulating the metabolism of glucose ${ }^{4}$. Some studies have demonstrated that a small amount of insulin may also be expressed in a subset of neurons in the central nervous system $^{5}$. After a meal, the level of blood glucose rises and insulin is secreted in response ${ }^{6}$. When the insulin level falls, glucose is released by the liver into the blood ${ }^{7}$. Insulin was first reported in 1921 in extracts of the pancreas by the Canadian scientists Frederick G. Banting and Charles H. Best, while Nicolae C. Paulescu, a Romanian physiologist, was independently working on an insulin-containing substance he called "pancrein" 8,9 . After the discovery of insulin by Banting and Best, work began to obtain purified insulin from the pancreatic extract. This was accomplished with the help of J. J. R. Macleod, a Scottish psychologist, and James B. Collip, a Canadian chemist ${ }^{10}$. Macleod and Banting shared the 1923 Nobel Prize in Medicine for their work on insulin ${ }^{11}$. Insulin was found to be a polypeptide in 1928 and its amino acid sequence was elucidated in $1952^{12}$.

Insulin is composed of two protein chains, with 21 amino acids in the A chain and 30 amino acids in the $B$ chain, totaling 51 in number, linked by disulfide bridges ${ }^{13}$. The pro-hormone proinsulin, from which insulin is derived, contains 74 amino acids, has a molecular weight of $5802 \mathrm{Da}$, and has an isoelectric point of $5.5^{14}$. Proinsulin secreted by the beta cells is relatively inactive under biological conditions, but after cleavage in two places yields the two chains ( $\mathrm{B}$ and $\mathrm{A}$ ) of the active hormone insulin, and the biologically inactive $\mathrm{C}$ peptide ${ }^{15}$. The $\mathrm{B}$ (helical central segment) and $\mathrm{A}$ chains become linked together by disulfide bonds with an antiparallel linkage on the C-terminal helix ${ }^{15}$. The A and B chains are joined 
${ }^{5}$ Department of Genetics, Institute of Hydrobiology, University of Chinese Academy of Sciences (UCAS), Wuhan, PR China

${ }^{6}$ Department of Chemistry, Lahore College for Women University, Lahore, Pakistan

${ }^{7}$ Department of Genetics, State Key Laboratory of Hybrid rice, College of Life Sciences, Wuhan University, Wuhan, PR China by a disulfide bridge which connects the $\mathrm{C}$ - and $\mathrm{N}$ terminal helices to $\mathrm{A}$ and $\mathrm{B}$ with a central terminal (Figure 1). Proinsulin, insulin, and the C-peptide are stored in granules in the beta cells, which release insulin into the islet cells' capillaries in response to a stimulus ${ }^{16}$. These capillaries empty into the portal vein, which carries blood from the intestines and stomach to the liver. After 30 minutes of exposure to hyperglycemia, the level of insulin in the blood will increase ${ }^{17}$. The healthy adult pancreas contains approximately 200 units of insulin, and the amount of daily insulin secretion into the circulatory system in healthy individuals ranges from 30 to 50 units ${ }^{18}$. Various factors stimulate the secretion of insulin, but the most important is the glucose concentration in oxygenated arterial blood that perfuses the islet cells ${ }^{19}$. When the concentration of glucose in the blood increases, large amounts of glucose are taken up and metabolized by beta cells, and insulin secretion increases ${ }^{20}$. On the other hand, as the concentration of glucose in the blood decreases, insulin secretion decreases, though insulin is secreted in small amounts even during fasting ${ }^{21}$. Insulin secretion may also be stimulated by fatty acids, amino acids, several hormones, and keto acids (resulting from fatty acid metabolism) secreted by the gastrointestinal tract ${ }^{21}$. Insulin secretion is inhibited by somatostatin and by sympathetic activation of the nervous system, which includes the fight or flight response ${ }^{22}$.

Primarily, insulin acts to stimulate glucose uptake in liver, muscle, and adipose (fat) tissues, which play a significant role in nutrient storage and metabolism ${ }^{23}$. Like other protein hormones, insulin binds with specific receptors on the outer membrane of target cells, which causes metabolic processes to take place within those cells. A key action of insulin is to stimulate the translocation of glucose transporters to the cell membrane from within the cell ${ }^{\mathbf{2 4}}$. Insulin is an anabolic hormone that promotes lipogenesis, glycogenesis, glucose uptake, and protein synthesis for skeletal muscle and fat tissues through the kinase tyrosine receptor pathway ${ }^{25}$. The prevalence of diabetes is increasing at an alarming rate, with estimates that the number of diabetic patients globally will reach 300 million by $2025^{26}$. As a result, the demand for insulin will soar to about $16,000 \mathrm{~kg} /$ year, and the productivity of the existing insulin expression systems will be insufficient to satisfy these future market demands. More efficient insulin expression methods must be developed, in addition to novel insulin delivery routes, such as through ingestion or inhalation. The current article discusses the various approaches for the synthesis of insulin.

\section{HISTORY OF INSULIN PRODUCTION}

Before insulin was discovered in 1921, patients with diabetes did not have long lives. The most successful therapy was to place diabetic patients on stringent carbohydrate-restricted diets. This could provide patients with a few more years of life, but could not entirely cure them. Patients have died of hunger as a result of strict diets consisting of only 450 calories per day ${ }^{27}$. Sir Edward Albert Sharpey-Shafer first proposed in 1910 that patients with diabetes had just one hormone lacking from their pancreas. Insulin is derived from the Latin word insula, which means "island" 12 . Frederick Banting, a young surgeon, discovered how to extract insulin from a dog's pancreas in 1921. The separated substance appeared to be "thick brown sludge," but they had no idea it would lead to life and hope for millions of diabetics ${ }^{28,29}$.

Leonard Thompson, a 14-year-old child dying of diabetes in a Toronto hospital in January 1922, became the first person to receive an injection of insulin. His critically high blood glucose levels decreased to near-normal levels within 24 hours ${ }^{30}$. The Nobel Prize for Medicine was awarded to Banting and Macleod in 1923. Eli Lilly, a pharmaceutical company, began mass-producing insulin shortly after. Manufacturers produced several slower-acting insulins throughout the decades that followed, with Novo Nordisk Pharmaceuticals, Inc. introducing the first in $1936^{31}$. Insulin from cows and pigs was used to treat diabetes for many years and saved millions of lives, though it was not optimal, as many people developed allergic responses to it ${ }^{32}$. The invention of DNA cloning by Stanley Cohen and Herbert Boyer heralded the beginning of genetic engineering, which allowed genes to be easily transferred across various biological species ${ }^{33}$. Their discovery led to the creation of various recombinant proteins with medicinal uses, including insulin and growth hormone. In 1978, E. coli bacteria were used to manufacture the first genetically engineered synthetic "human" insulin. Eli Lilly went on to market the first commercially accessible biosynthetic human insulin under the brand name Humulin in 1982, which was authorized by the FDA for medicinal use in humans ${ }^{34}$.

\section{PRODUCTION STEPS OF INSULIN}

The first insulin production method that will be discussed here involves the synthesis of proinsulin. An alternative two-chain method where the $\mathrm{A}$ and $\mathrm{B}$ chains of insulin are produced separately can also be used. Recombinant E. coli are used to produce adequate quantities of proinsulin. This recombinant protein is produced by incorporating proinsulinproducing plasmids into $E$. coli ${ }^{35}$. The transformed 


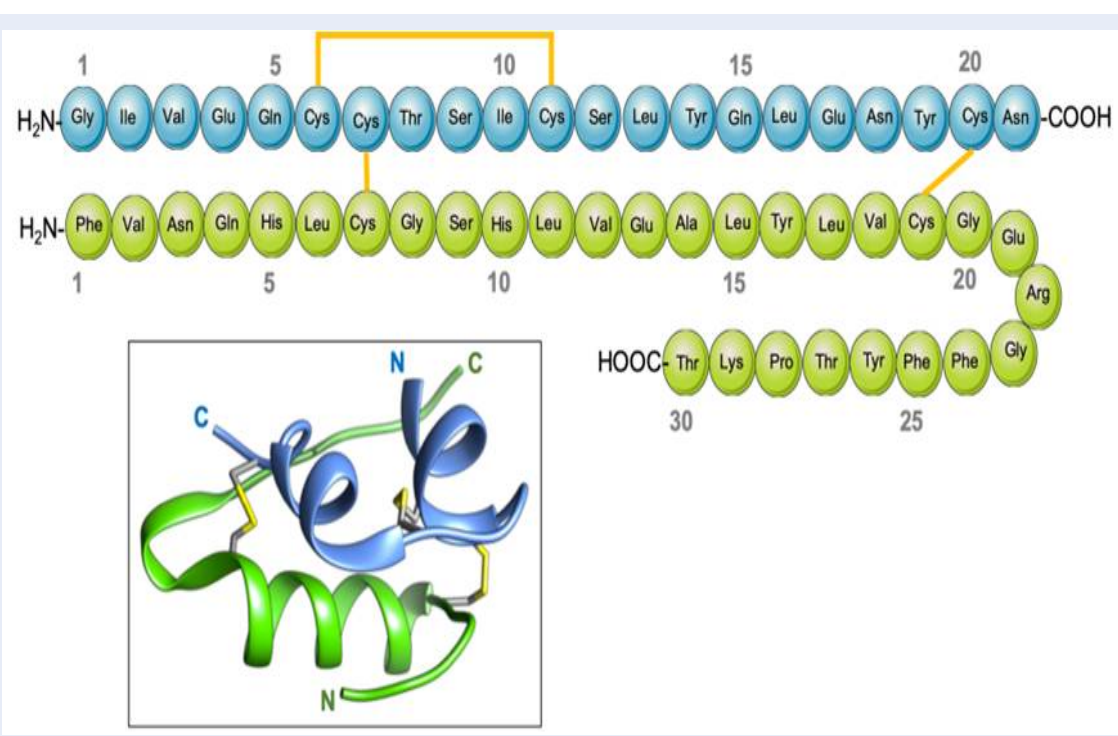

Figure 1: Comparative analysis of different expression systems used for production of human insulin. https://doi.org/10.6084/m9.figshare.16702819.v1

cells are then grown on tryptic soy broth containing the antibiotic kanamycin monosulfate. The plasmid contains a kanamycin monosulfate resistance gene along with the proinsulin coding genes, so the transformed E. coli can survive in the broth. However, kanamycin monosulfate kills the $E$. coli cells that have not been transformed ${ }^{36}$.

After the transformed E. coli have been obtained, the next goal is to increase the cell count to initiate the production of proinsulin inclusion bodies. For this purpose, the original transformed cells that were grown in the tryptic broth and kanamycin monosulfate are then inoculated and grown in a bioreactor under controlled parameters to maximize insulin production. These parameters include temperature $\left(37^{\circ} \mathrm{C}\right), \mathrm{pH}(7)$, foam, and feed. The oxygen level is kept at a tension level of $30 \%$ and it is maintained by adjusting the quantity of glycerol-feeding ${ }^{37}$.

\section{Fermentation and Parameters}

In this method, six $200 \mathrm{ml}$ test tubes are used to grow $0.5 \mathrm{~g}$ of the initial transformed E. coli cells in 1lL tryptic soy broth solution with $0.5 \mathrm{~g}$ of kanamycin monosulfate. After the cells have been left to grow in the medium for 24 hours at $37^{\circ} \mathrm{C}$ they are inoculated in a bioreactor to promote growth and production of proinsulin $^{38}$.

After 24 hours, the transformed E. coli has consumed and depleted all the nutrients in the test tubes, hence they are placed in the bioreactor to support further growth. This bioreactor has a total volume of $23 \mathrm{~L}$ and a working volume of 16L. 1L of E. coli and depleted growth medium is taken and mixed with $9 \mathrm{~L}$ of fresh growth medium in the bioreactor (Figure 2). Now, these cells will receive carbon from glycerol and yeast, nitrogen from ammonium sulfate and thiamine, and inorganic nutrients from potassium dihydrogen phosphate and dipotassium phosphate, which also act as buffers to maintain $\mathrm{pH}$. Trace elements will be provided by sodium citrate, magnesium sulfate, and a vitamin solution ${ }^{39}$.

The conditions within the bioreactor are monitored by biosensors. The $E$. coli reaches its maximum growth within 28 hours, after which it is removed from the surrounding medium through centrifugation.

\section{Cell Isolation by Centrifugation}

Cell isolation is the first step in down streaming of the insulin made by transformed E. coli cells. This process is also referred to as cell harvesting because the proinsulin inclusion bodies are harvested using both filtration and centrifugation. Since E. coli has the highest density of all the components in the growth medium, the bacterial cells settle to the bottom after centrifugation at $7500 \mathrm{xg}(8185 \mathrm{rpm})$ for 10 minutes. Then the supernatant is discarded and the dense mixture left behind is further processed since it contains a higher concentration of bacterial cells ${ }^{40}$.

\section{Cell Lysis by Homogenization}

The proinsulin inclusion bodies present inside the cell contain insulin precursor products in the form of 


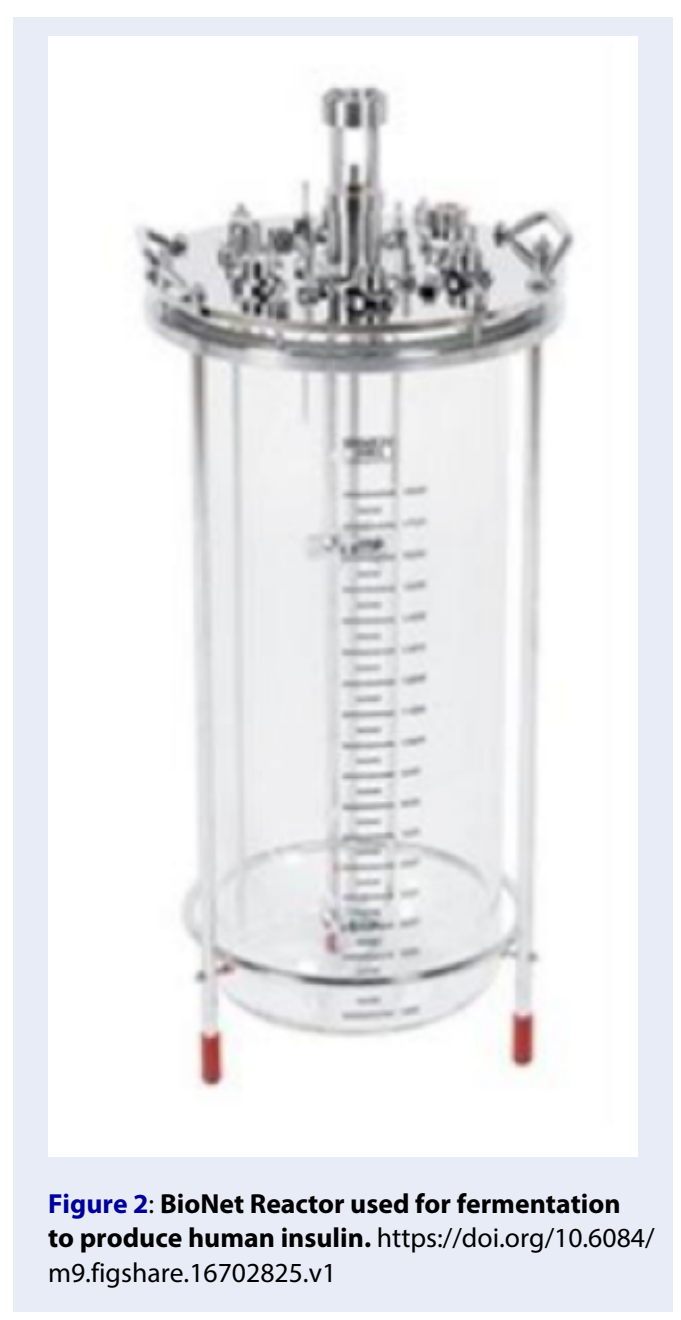

proinsulin fusion proteins. Since they are present in dense aggregates, they are protected from being processed into the soluble form within the cytoplasm. To release these inclusion bodies, various methods of cell membrane disruption are available. In this particular process, high-pressure homogenization with a bladetype homogenizer, and chemical alkali treatment are used $^{41}$.

The bacteria and medium are injected into the chamber of a high-pressure homogenizer with intense speed, and as a result, when the mixture encounters the blade present within the chamber, a condition of high turbulence and shear is created leading to compression, acceleration, and a pressure drop. The cell membrane is disrupted due to these forces, releasing the cytoplasmic contents. However, the proinsulin molecules remain intact. The pressure provided by the homogenizer is 45,000 PSI with a flow rate of 150 $\mathrm{ml} / \mathrm{min}$. Therefore, it can homogenize a 3L mixture of cells and medium in 20 minutes. After homogeniza- tion, the proinsulin must be separated from cell debris and intracellular material ${ }^{42}$.

\section{Inclusion Body Separation by Centrifuga- tion}

After the E. coli have been lysed, the inclusion bodies need to be isolated from the cell debris. For this purpose, centrifugation can be used for reverse osmosis. Since the proinsulin inclusion bodies are dense, they will sink to the bottom. However, the speed of centrifugation must be higher ( $15000 \mathrm{x}$ g for 30 minutes) than before, since the inclusion bodies have a lower density than the intact bacterial cells. After centrifugation, the supernatant is discarded while proinsulin and some impurities remain in the tube ${ }^{37}$.

\section{Solubilization of Inclusion Bodies}

After the separation of inclusion bodies, proinsulin is in an insoluble form and therefore must be solubilized. This is accomplished through the addition of denaturing agents such as urea or guanidium hydrochloric acid, which will release the fusion proteins. This process is followed by the addition of either $\beta$ mercaptoethanol or DTT, which are reducing agents, to break the disulfide bonds present within the proinsulin fusion proteins.

In the traditional proinsulin procedure, after solubilization, a cleavage step for the preparation of proinsulin is performed. This step can also be performed later in the processing. It involves adding cyanogen bromide and $70 \%$ formic acid to cleave the peptide linker between proinsulin and its fusion protein partner ${ }^{43}$.

\section{Sulfitolysis}

Sulfitolysis first involves breaking the disulfide bonds by adding reducing agents. These bonds get broken during solubilization or other earlier steps of purification. The process of sulfitolysis is performed along with 6 hours of solubilization, and $0.8 \mathrm{M} \mathrm{Na}_{2} \mathrm{SO}_{4}$ and $0.3 \mathrm{M} \mathrm{Na}_{2} \mathrm{SO}_{4}{ }^{\star} \mathrm{H}_{2} \mathrm{O}$ are added to facilitate oxidation and maintain the unfolded form of proinsulin. Sulfite $\left(\mathrm{SO}_{3}\right)$ ions are added to cysteine molecules, which prevents the formation of incorrect disulfide bonds ${ }^{\mathbf{4 4}}$. All of the cysteine residues in the proinsulin molecule have sulfite ions added. However, the $\mathrm{ZZ}$ tail has no cysteine residues, therefore it remains unaltered and is utilized in further downstream processes.

\section{Additional Separation}

Before renaturation, the impurities and reagents from solubilization and sulfitolysis must be removed via centrifugation at $17700 \mathrm{x}$ g for 33 minutes ${ }^{45}$. 


\section{Dialysis}

This process is used to remove the previously used denaturants and dissolved reagents without chemically modifying the fusion protein product. It involves the addition of buffers such as $10 \mathrm{mM}$ Tris- $\mathrm{HCl}$ (4 repetitions) to remove reagents including urea, DTT, and $\beta$-mercaptoethanol, and initiate the refolding process of the proinsulin fusion protein ${ }^{46}$.

\section{Renaturation}

The process of renaturation involves the correct folding of proteins, which depends heavily upon the correct formation of disulfide bonds. Renaturation is carried out for 20 hours at $4^{\circ} \mathrm{C}$ with the addition of $1 \mathrm{M}$ glycine-sodium hydroxide buffer ( $\mathrm{pH} 10.5$ or higher) and $\beta$-mercaptoethanol at an 18:1 molal ratio to the fusion protein. There are several methods available. Two commonly used methods are (1) the use of oxidative buffers such as low molarity Tris- $\mathrm{HCl}$ or glycinesodium hydroxide to oxidize the reduced proinsulin, or (2) conversion of the proinsulin to the S-hexasulfonated form via sulfothiolysis using sodium sulfite, followed by the addition of redox reagents such as cysteamine, GSH or cysteine couples ${ }^{47}$.

Correct folding is the critical factor determining the yield of proinsulin products. Factors to optimize refolding include using an accelerated oxidation rate, basic $\mathrm{pH}$ of 9 , and a high concentration of redox reagents. Even under optimized conditions, the yield is $60 \%$ to $70 \%$. Therefore this step of the production process requires further research ${ }^{48}$.

\section{Volume Reduction}

After renaturation, the reagents and buffers that were used need to be removed so that the proinsulin product can be isolated. This can be done by the addition of weak acid for adjustment of $\mathrm{pH}$ followed by centrifugation at $17700 \mathrm{x}$ g for 33 minutes. An alternative method can be sedimentation ${ }^{49}$.

\section{Affinity Chromatography}

It has been estimated that more than half of the cost of insulin production is spent on downstream purification processes rather than the growth of transformed bacteria. Therefore, purification techniques need to be time- and cost-effective, and provide a high yield of product that is pure enough for human use. This process involves volume reduction via site-specific cleavage chromatography of insulin from the proinsulin method $^{50}$.

This method involves the purification of ZZ-R proinsulin through IgG affinity chromatography using an
IgG-Sepharose column. It involves the use of acetic acid at $\mathrm{pH} 8$ as the supernatant, which is centrifuged for 20 minutes before being used. $50 \mathrm{ml}$ of the solution is loaded at a flow rate of $3 \mathrm{ml} / \mathrm{min}$, which means that approximately $2.5 \mathrm{~g}$ of $\mathrm{ZZ}-\mathrm{R}$ proinsulin will be passed through the HR16/10 diameter column, which contains $12 \mathrm{ml}$ of IgG-Sepharose. The solution is added a total of 6 times, and the last three loads use $10 \mathrm{mM}$ of sodium acetate at $\mathrm{pH} 8^{\mathbf{5 1}}$.

The results of affinity chromatography are observed using SDS-PAGE on a homogenous $12 \%$ gel. It involves the use of size exclusion chromatography with a Superdex 75 PC3.2/10 column with the addition of $200 \mathrm{mM}$ sodium phosphate buffer at a flow rate of $100 \mathrm{ml} / \mathrm{min}$. ZZ-R proinsulin is resistant to degradation by proteases when passed through affinity chromatography. It is then further purified by size exclusion chromatography, whose recovery rate is $70 \%$. Most of the recovered proinsulin is a monomer, while other forms of ZZ-R proinsulin are also present in small quantities ${ }^{52}$.

\section{Site-Specific Cleavage}

After IgG chromatography, the purified ZZ-R proinsulin undergoes ultra-filtration which reduces its volume by 5 times, increasing its concentration to $12 \mathrm{ml} / \mathrm{min}$. Ultra-filtration is followed by cleavage of proinsulin into the C-peptide and insulin using trypsin and carboxypeptidase B. Trypsin is used for the breakdown of protein in the digestive system while carboxypeptidase is used for cleavage of proinsulin at a specific site to convert proinsulin into native insulin and the C-peptide. About 1:1000 by mass of trypsin to $\mathrm{ZZ}-\mathrm{R}$ proinsulin is used, while the quantity of carboxypeptidase $B$ is double that of ZZ-R proinsulin. The enzymatic reaction is allowed to proceed for 30 minutes, after which it is stopped by the addition of trifluoroacetic acid, carboxylic acid, and a common buffer at a $\mathrm{pH}$ of 3. $20 \%$ acetonitrile is also added. The resulting solution is stored at $4^{\circ} \mathrm{C}$ before further purification using reverse-phase chromatography ${ }^{43,51}$.

\section{Reverse-Phase High-Performance Liquid Chromatography}

Reverse-phase high-performance liquid chromatography (RP-HPLC) is used to separate the C-peptide and human insulin. RP-HPLC is a common method used to analyze insulin products since it can separate insulin into its different species, and the use of high pressure increases the speed of the process and purity of the product. RP-HPLC involves a non-polar 
stationary phase and a polar mobile phase. Since insulin is non-polar and large, it adheres to the stationary phase column whereas the mobile phase contains methanol or acetonitrile in a buffer solution to analyze the insulin. The wavelengths used for the detection of insulin are 190 to 220 nanometers. Conveniently, both the chains of insulin can be separated using this method. For the A chain, trifluoroacetic acid is used while for the $\mathrm{B}$ chain, formic acid is used. However, to separate the C-peptide, the best technique is gel chromatography with $1 \mathrm{M}$ acetic acid as a buffer ${ }^{37,53}$.

\section{Polishing with Zinc Complexation and Saline Dilution}

The goal during insulin administration is to quicken its activation time and prolong the peak hours. When using regular insulin, R-insulin, the activation time is 30 to 60 minutes, while it reaches a peak after 2 to 4 hours of administration. This means that approximately 4 to 6 injections are needed daily. The primary methods to prolong the activity of insulin are by inhibiting its immediate use by cells, preventing the liver from removing it, and stabilizing it in the bloodstream ${ }^{\mathbf{5 4}}$.

Eli Lilly and Co. have devised a method that requires only daily 2 insulin injections for people with an active lifestyle. They used zinc ions to form crystal complexes with insulin, named $2 \mathrm{Zn}$ insulin, which have a hexagonal configuration while exhibiting axial symmetry, hence slowing the release of insulin to the body and preventing its immediate use by cells ${ }^{55}$. Cobalt can also be used for this purpose. These metallic ions form weak ionic bonds with insulin, causing insulin molecules to congregate and form suspended crystals. The formation of crystals is achieved through batch crystallization, and the solution is stored at $4^{\circ} \mathrm{C}$. The better and more regular the crystal, the longer it can remain active in the bloodstream ${ }^{56}$.

Moreover, crystallization with zinc can help alleviate zinc deficiency, which is commonly found in people with diabetes. Additionally, insulin is naturally stored as zinc hexamers in the beta cells of the islets of Langerhans. Commonly, $70 \%$ of the complexed crystalline insulin is mixed with $30 \%$ monomeric insulin, which allows for immediate use of the monomeric insulin by the body, while the complex insulin is released slowly over an extended period ${ }^{27,57}$. The stepby-step procedure for human insulin production is illustrated in Figure 3.

\section{ALTERNATIVE METHODS FOR INSULIN PRODUCTION}

The second commercial method for insulin production is the two-chain method, in which the A chain and the $B$ chain of insulin are produced separately and then fused (Figure 4). Here, these 2 polypeptides are cultured in bacteria in two different fermenters and then purified. The purified A and B chains are then incubated under oxidizing conditions to form the disulfide bonds that are present in human insulin ${ }^{37}$.

\section{Bio-production Steps \\ Gene Isolation}

Complementary DNA (cDNA) molecules encoding chain $A$ and chain $B$ are obtained from human insulin mRNA using reverse transcription ${ }^{34}$. The cDNAs of both chains are amplified by PCR.

\section{Insertion into the Plasmid}

Two plasmids are cut using restriction enzymes to insert the DNA sequence for the A chain or the B chain separately. Each chain is extended with an ATG initiation codon on the 5 ' terminus to begin the translation process, while the termination signal is present on the plasmid at 3 'end of the restriction sites ${ }^{\mathbf{6 0}}$. The restriction sites of EcoR1 and BamH1 contain one of the chain genes in both plasmids. The plasmid also contains a lacZ gene, which encodes for $\beta$-galactosidase, allowing for colony screening. Specific DNA ligases are added to bind the inserted chain gene into the plasmid $^{61}$.

\section{Transfection}

The entry of recombinant plasmids into bacterial cells is called transfection. Different techniques can be used for the transformation of $E$. coli, such as treatment with $\mathrm{CaCl}_{2}$ or electroporation techniques. After the plasmid's entry, the cells become transformed ${ }^{62}$.

\section{Medium Preparation}

$\mathrm{LB}$ broth is used as a culture medium for E. coli. It is first dissolved and the solution is autoclaved for sterilization, and then ampicillin and lactose are added. The medium is inoculated with transformed $E$. coli cells ${ }^{57}$. STR bioreactors are used for fermentation of the two E. coli strains encoding the insulin chains. The bioreactors are sterilized and the $\mathrm{pH}, \mathrm{pO}_{2}$ probe, condensers, and air inlet are calibrated ${ }^{63}$.

\section{Bioreactor Fermentation}

Shake flasks are used for small-scale fermentation of recombinant $E$. coli cells encoding the A and B chains in the enriched medium, which are then used for the large-scale fermentation process ${ }^{63}$. The ampicillin resistance and lac $Z$ genes present on the plasmids are used for the identification of successfully 


\section{Inoculum Preparation}

\section{Media Preparation}

\section{Fermentation}

Harvesting

Centrifugation

Cell disruption- Homogenization

Inclusion Bodly Separation

Solubilize Inclusion Bodlies

Sulfitolysis

Centrifugation

Dialvsis

Renaturation

Centrifugation

Purification

Storage
-Six $200 \mathrm{ml}$ test tubes need to grow for initial culture.1l of tryptic soy broth. $-0.5 \mathrm{~g}$ of kanamycin monosulfate

$-5 \mathrm{~g}$ of the genetically altered $\mathrm{E}$.Coli.

Grow for 24 bours at $37^{\circ} \mathrm{C}$

Bioreactor with 23L total volume \& $16 \mathrm{~L}$ working volume. - $1 \mathrm{~L}$ of E.coli \& depleted growth medium is mixed with 9L of growth media - Buffer-pota dihydrogen phosphate \& dipota. phosphate. pH: at 7 - Na citrate, Mg sulphate, a trace element solution, \& a vitamin solution -oxygen tension is kept at a tension level of $30 \%$.

-Within a bioreactor the temperature, PH, foam, \& feed can be controlled automatically to yield maximum result.

$-10 \mathrm{~L}$ total working volume 31 hour growth phase $\mathrm{pH} 7,37^{\circ} \mathrm{C}$

-Cell Harvesting Parameter= 7500g(8183Tpm) for 10 minutes. (Filtration and centrifugation)

-High pressure or alkali treatment

-High pressure or alkali treatment

-Parameter= 45,000 PSI \& Flow rate:150ml/min ( 3LE.coli cell mixture for

20 minin)

-Inclusion Body Separation Parameter. 15000g(11573rpm)for 30 min (centrifugation or reverse osmosis)

- Denaturing agent: urea or guaminidinium-HCL.(GdmHCL)

-Parameter-Stiming for 6hr at $37 \mathrm{C} 8 \mathrm{M}$ Urea added

•Peformed during 6hr solubilizing step $0.8 \mathrm{M} \mathrm{Na} \mathrm{SO}_{4} 0.3 \mathrm{M} \mathrm{Na}_{2} \mathrm{SO}_{4} \neq 2 \mathrm{H}_{2} \mathrm{O}$

-Additional Separation: 17700g(12571rpm) for 33 min

Equipment: Spectrajpar 1 membrane,MWCO 6-8000.

-Parameters: 4 repetitions Washing buffer.10mM Tris-HCl(pH8)

-Parameters: Stiming for 20hr at $4 \mathrm{C} 1 \mathrm{M}$ glycine $\mathrm{NaOH}$ (pH 10.5+) 18:1 mola ratio of B-mercoptoethanol to fusion protein

-Volume Reduction Parameter: 17700g (12571rpm) for 33 min -Priorto downstream purification.Reducing the volume of the renatured protein.

Affinity chromatography. 0.3M acetic acid added until pH of 8 is reached - Site-specific cleavage: Trypsin \& carboxypeptidaseB, Acetonitrile, 作-peptide \& human insulin. -Polishing: $\mathbf{Z n}+3$ complexing and saline dilution

-At $4^{\circ} \mathrm{C}$, for not to allow the insulin to completely come out of solution.

Figure 3: Diagrammatic representation of protocol involved in human insulin production. https:// doi.org/10.6084/m9.figshare.16702828.v1 


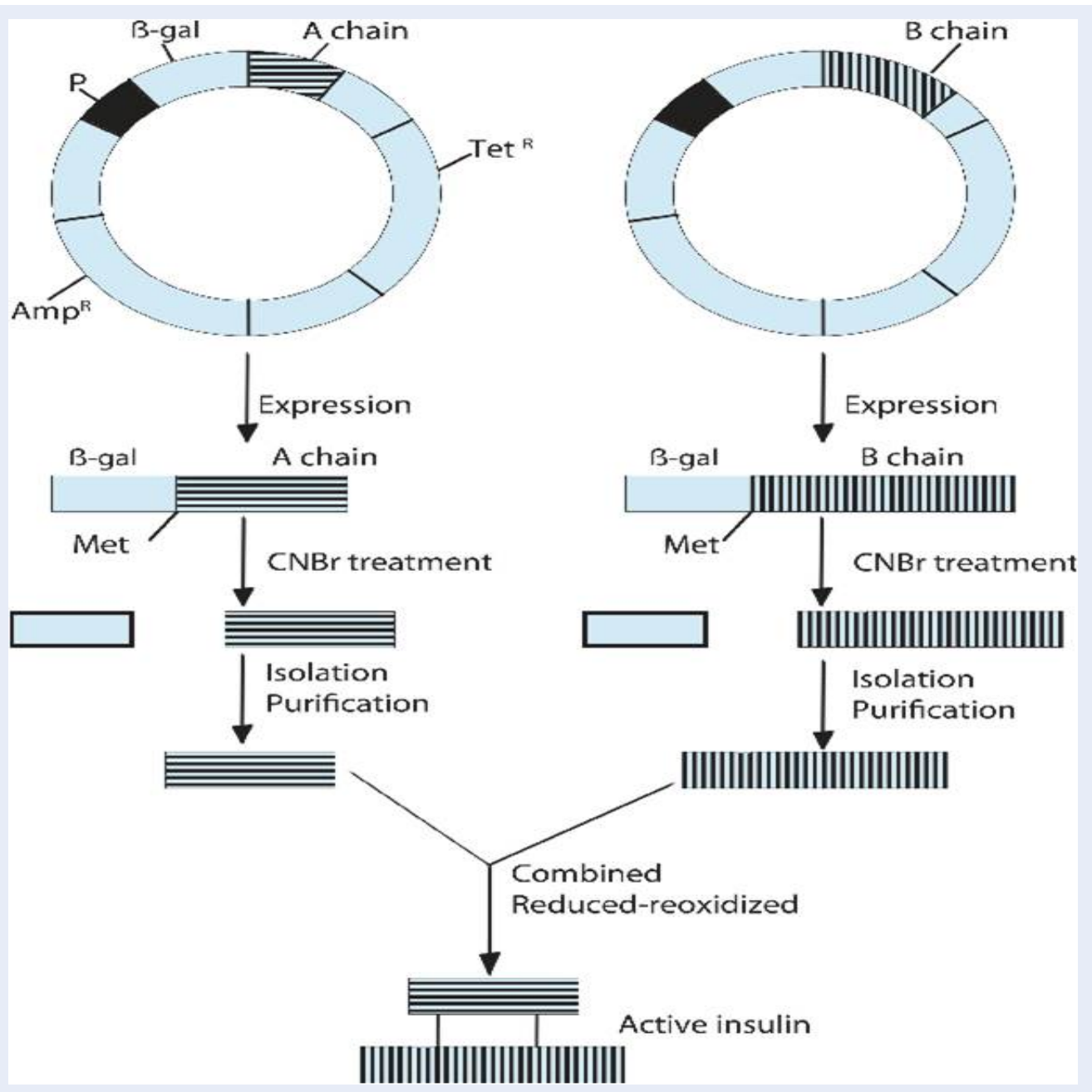

Figure 4: Mechanism of producing human insulin by utilizing chain method ${ }^{58}$. https://doi.org/10.6084/m9.figshare.16702831.v1

transformed cells, as they show resistance against the ampicillin present in the growth medium and encode $\beta$-galactosidase. These successfully transformed cells are retained for replication under optimal conditions and then transferred into a bioreactor for commercial production. The A and B chains are synthesized as their respective E. coli strains replicate in separate fermenters ${ }^{64}$.

\section{Crude Product Isolation}

The bacterial cells are removed from the bioreactor tank and must be lysed with one of several methods, such as enzyme digestion, sonication, or freezing and thawing of cells. The use of lysosome enzymes is preferred for large-scale operations, as it digests the bacterial outer layer to release the insulin into the surrounding media, so detergents can later be added to remove the cell wall ${ }^{64}$.

\section{Purification}

Cell components are separated from the two desired insulin chains. Gel filtration and ion-exchange chromatography methods are used to remove impurities ${ }^{64}$

\section{Insulin Chain Isolation}

The isolated purified protein has an insulin chain fused with $\beta$-galactosidase, as it has been linked with the gene incorporated into the plasmid and translated along with it. Cyanogen bromide is used to separate the insulin chains from $\beta$-galactosidase, as it splits the protein at the methionine residue which begins the $\beta$ galactosidase protein ${ }^{65}$. 


\section{Chain Joining}

The insulin chains (A and B) are treated with sodium dithionite and sodium sulfite to form the disulfide bonds that bridge the chains. This whole process is called reduction-reoxidation, and it is induced by $\beta$ mercaptoethanol and air oxidation to synthesize human insulin ${ }^{58}$.

\section{Reverse-Phase High-Performance Liquid Chromatography}

RP-HPLC is performed to remove the remaining impurities or reagents. The purified, active human insulin can then be packed and sold by the industry ${ }^{\mathbf{6 6}}$.

\section{DIFFERENT EXPRESSION SYSTEMS}

Recombinant human insulin is usually commercially produced in E. coli or S. cerevisiae. With the E. coli expression system, the inclusion bodies of insulin precursors (IPs) are produced, which are then solubilized and refolded to create active insulin. The yeast expression system yields the IPs in culture-supernatant, therefore it is often selected for commercial production. Several other insulin expression systems are being studied ${ }^{37}$. Some yeast strains are being manipulated to explore insulin production. Additionally, many mammalian cells and plants are under investigation for their suitability for large-scale production ${ }^{67}$. To fulfill the world's requirement for insulin of $16,000 \mathrm{~kg}$ per year, novel and efficient expression systems must be developed ${ }^{37,68}$.

\section{E. coli}

The E. coli expression system was the first expression system used to produce human insulin in 1978, with the use of recombination technology in the two-chain method. This expression system is preferred for the large-scale production of R-insulin, as E. coli grows rapidly on cheap media, is easy to handle, and can be genetically manipulated ${ }^{69}$. However, several aspects limit its usefulness, including loss of plasmids, development of antibiotic properties, lack of posttranslational modifications (PTMs), inclusion bodies' accumulation within the cells, improper folding, proteolytic digestion, and poor secretion that makes protein recovery difficult ${ }^{70}$. Further research and the development of new technologies have tried to solve these problems. Some of the approaches are mentioned here.

Recently a new PCR-based approach was used for the cloning of human insulin, eliminating several steps such as affinity tags, tedious protein renaturation, inclusion body recovery steps, and the enzymatic cleavage of the C-peptide of insulin, making this method novel and more efficient ${ }^{45}$.

In 2019, Zieliński et al. reported the construction of the novel pIBAINS expression vector and the establishment of 20 novel E. coli strains, which provide greater efficiency of recombinant insulin production per liter of medium ${ }^{46}$.

- Protease-deficient E. coli strains carry a mutation that eliminates protease production, which helps to reduce the proteolytic degradation of $\mathrm{R}$ insulin. The BL-21 E. coli strain lacks the lon (cytoplasmic) and ompT (periplasmic) protease genes, and can also be used to improve the yield of insulin ${ }^{70}$.

- Insulin gene expression can also be increased by replacing codons with higher expression codons present in rare strains of $E$. coli. Similarly, the co-expression of tRNA coding genes will enhance the yield of heterologous proteins in this expression system. The BL-21, BL21 CodonPlus-RIL, and Rosetta strains include such codons, for example, AGG, AGA, CGG (arginine), AUA (isoleucine), GGA (glycine), and CCC (proline). Introducing these higher expression codons in engineered strains of $E$. coli can result in better yield ${ }^{37,71}$.

- Chaperones can be used to avoid the accumulation of inclusion bodies in E. coli, as they help prevent protein aggregation by helping to refold and resolubilize the misfolded proteins. GroEL, GrpE, DnaK, and trigger factor are common chaperones used in this application, and can be used independently or in a combined form ${ }^{72,73}$.

\section{Yeast Expression Systems}

Yeast is another commercially-used expression system for heterogeneous protein production with recombinant technology because of its PTMs. Such PTMs include acylation, phosphorylation, and Nand O-linked glycosylation of proteins ${ }^{74}$. Yeast can easily be scaled up in bioreactors and its use is costeffective, which makes it a potential candidate as an expression system for the production of recombinant insulin. However, a factor of concern when using yeast as an expression system is that proteins synthesized in yeast have high-mannose $\mathrm{N}$-glycosylation. This shortens the half-life of recombinant proteins in vivo and activates an immune response in humans because proteins with this modification are considered foreign antigens. Thus, yeast has to be humanized before use by modifying its $\mathrm{N}$-glycosylation pathways to create less immunogenic products for humans ${ }^{75}$. 


\section{Saccharomyces cerevisiae}

S. cerevisiae has been used commercially as a yeast expression system for insulin since the 1980s by creating proinsulin, which links the $\mathrm{A}$ and $\mathrm{B}$ chains via a short synthetic C-peptide ${ }^{37,64}$. The $\alpha$-factor signal sequence helps in the synthesis of the chains and increases proinsulin expression to $80 \mathrm{mg} / \mathrm{ml}^{76}$. Proinsulin is converted to active insulin by a trypsinmediated transpeptidation reaction with a threonine ester. Other insulin analogs synthesized using yeast include:

- Fast-acting insulin for human treatment is produced by Novo Nordisk in the S. cerevisiae expression system. In this product, the residue in the $28^{\text {th }}$ position of the proinsulin B chain has been replaced with aspartic acid. This modification increases the inter-chain repulsion to decrease self-association, which aids in dispersion in the blood ${ }^{77}$

- Insulin Detemir is a long-acting analog, produced in S. cerevisiae commercially in 2004 by Novo Nordisk ${ }^{78}$. Its sequence has been modified by the removal of threonine at the $30^{\text {th }}$ position of the B chain along with the attachment of a C14 fatty acid at the $29^{\text {th }}$ position of the same chain ${ }^{79}$. Such modifications help the insulin to bind with albumin in the plasma, which prolongs the duration of the insulin's effect to a full day.

\section{Pichia pastoris}

The high cell-density, methylotrophic yeast $P$. pastoris is also used commercially for insulin production ${ }^{\mathbf{8 0}}$. A special feature of this yeast expression system is the presence of the methanol-inducible alcohol oxidase1 promoter (AOX-1), which increases the cell density under simple cultivation strategies to help in the large-scale production of recombinant proteins. Unlike S. cerevisiae, P. pastoris does not hyperglycosylate its secreted heterogeneous proteins, proving advantageous for use in the creation of human therapeutics ${ }^{81}$. Both yeast expression systems do carry out high-mannose N-glycosylation, but in P. pastoris, the oligosaccharide chain consists of 8-14 mannose residues/chain, which is far shorter than the 50-150 mannose residues/chain added by $S$. cerevisiae. Heterogeneous protein expression attained by $P$. pastoris is approximately $30 \%$ of its total cell protein, which is much higher than S. cerevisiae ${ }^{82}$. Such characteristics make $P$. pastoris an attractive expression system for use in the commercial production of recombinant human insulin and its analogs. The highest yield of insulin precursor, $1.5 \mathrm{~g}$ of IP/L of culture broth, was recorded from the $P$. pastoris expression system ${ }^{83}$.

\section{Transgenic Plants}

Of recent interest in the field is the production of recombinant or heterogeneous proteins from transgenic plants, which have the advantage of low cost and high protein quality ${ }^{84}$. Plants do not have human pathogens and because they are eukaryotic, their PTM machinery is more similar to humans than that previously described in yeast ${ }^{85}$. The mechanism involved in producing human insulin in transgenic plants is illustrated in Figure 5.

\section{Arabidopsis thaliana}

With recent experimentation, the human insulin gene has been successfully expressed in oilseeds of the Arabidopsis thaliana plant ${ }^{37}$. This plant has a short generation time of almost 6 weeks and can easily grow under laboratory conditions with limited sunlight. The genome of $A$. thaliana is completely known, making it easier to perform further research on recombinant insulin production. Each plant is capable of generating approximately 10,000 to 30,000 seeds ${ }^{86}$. The insulin is expressed in subcellular organelles of plantlike oil bodies which, along with a high amount of protein expression, makes its recovery easier. Inside the oilseeds, the oil bodies are encapsulated by a hydrophobic tri-acylglycerol phospholipid membrane, and their outer wall is made up of oleosins ${ }^{87}$. These oil bodies can be easily separated from other seed components by liquid-liquid phase separation methods, reducing the need for chromatographic steps to purify the insulin. Experimental results showed that the insulin accumulation in transgenic seeds is up to $0.31 \%$ of the total seed proteins ${ }^{88}$. Trypsin digestion is used to cleave the oleosin from the oil bodies, which also purifies and matures the active insulin via simple purification methods. The use of seeds as an expression system is also advantageous because the insulin can be stockpiled until it is required.

\section{Tobacco and Lettuce Plants}

The tobacco plant exhibits higher seed germination and survival rates, while the lettuce plant is widely consumed across the globe and is a very attractive expression system ${ }^{89,90}$. The chloroplasts of these plants are used to synthesize proinsulin. The insulin chains ( $\mathrm{A}$ and $\mathrm{B}$ ) and the $\mathrm{C}$-peptide become fused with subunits of cholera toxin- $\mathrm{B}^{\mathbf{9 1 , 9 2}}$. The reported data show that old leaves of tobacco plants contain almost $47 \%$ 


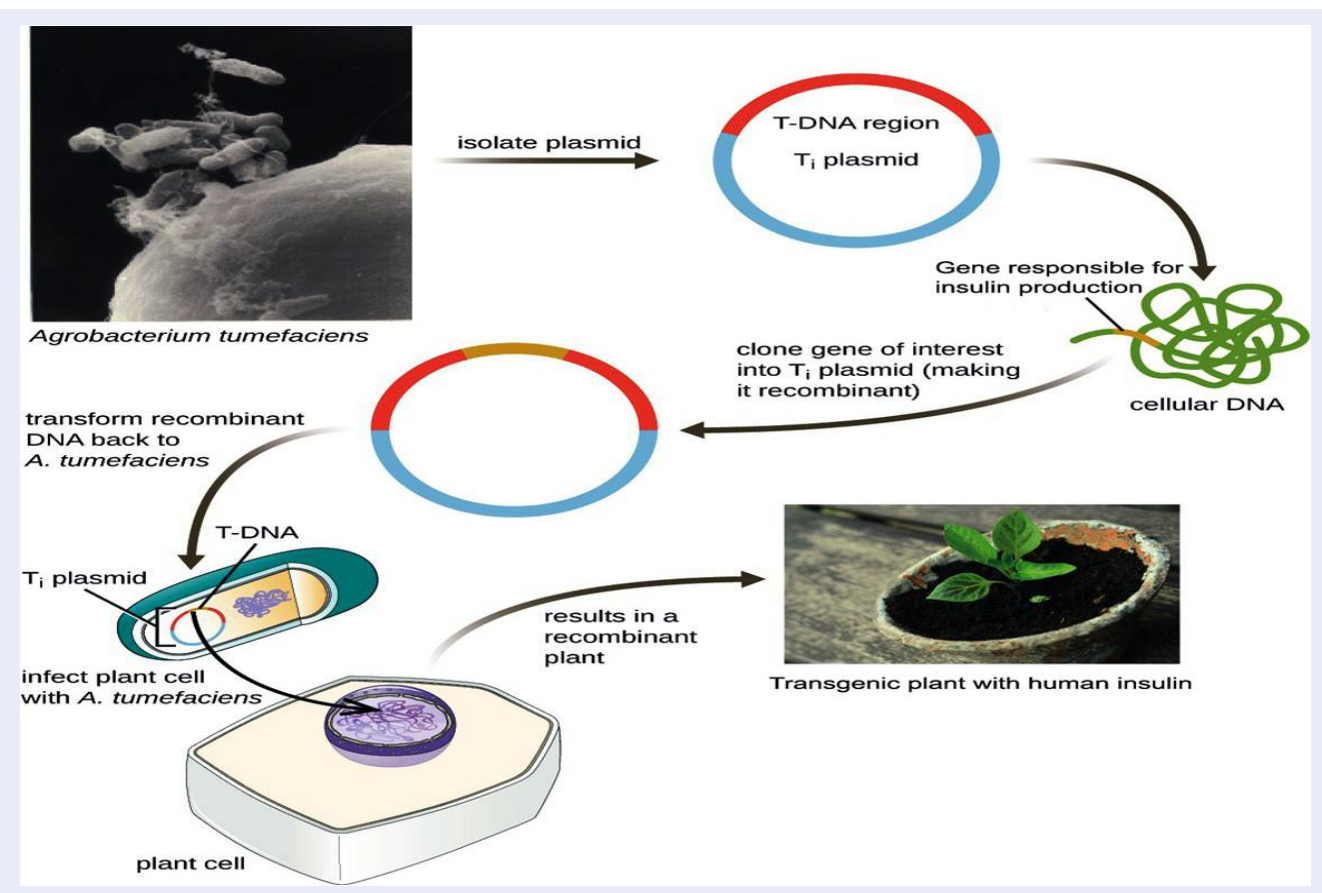

Figure 5: Mechanism involved in developing Agrobacterium mediated transgenic plant for human insulin production. https://doi.org/10.6084/m9.figshare.16702834.v1

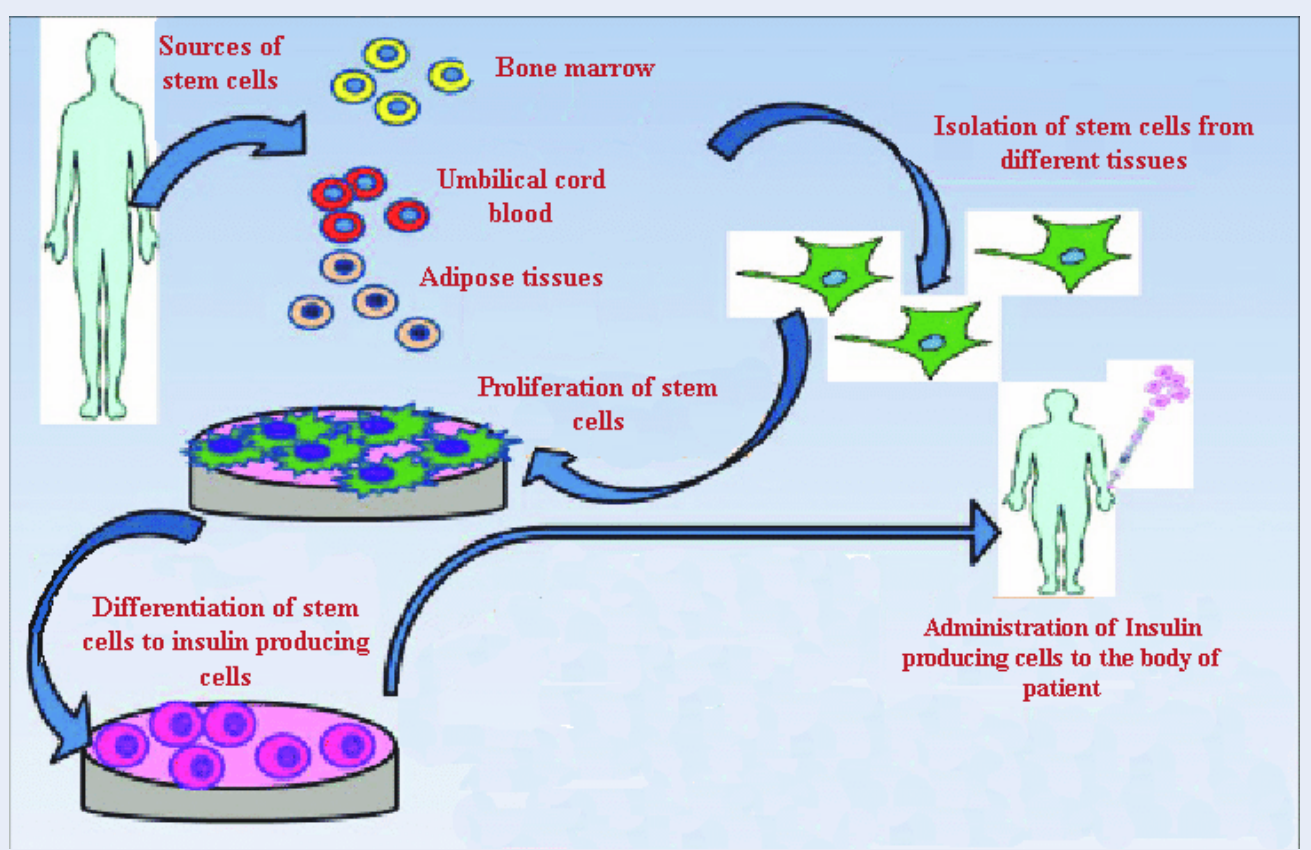

Figure 6: Representation of mechanism involve in isolation and differentiation of various types of stem cells to human insulin producing cells ${ }^{59}$. $\mathrm{https}: / /$ doi.org/10.6084/m9.figshare.16702837.v1 
of proinsulin out of their total leaf proteins ${ }^{91}$. In old leaves of lettuce, up to $53 \%$ of total leaf proteins were recorded as proinsulin ${ }^{91}$. The extracted insulin is found to be very stable and has up to $98 \%$ purity when cleaved by Furin protease treatment to release the insulin peptides. Oral delivery of plant cells also shows similar results as commercially available insulin. The recorded yield of proinsulin by these plants is $3 \mathrm{mg} / \mathrm{g}$ of leaves, which indicates that one acre of such plants could produce 20 million daily doses of insulin every year $^{37,72}$.

\section{Strawberry Plant}

Strawberry (Fragaria ananassa Duch.) is one of the world's most significant and popular fruits and contains several vitamins, minerals, anthocyanins, and essential amino acids that contribute to human health ${ }^{\mathbf{9 3 , 9 4}}$. However, the edible nature of the strawberry makes it a useful plant for insulin production, as it can be used as a vehicle for oral administration. Also, strawberries contain levulose, which is quickly absorbed and decomposed in the body and does not affect people with diabetes ${ }^{95}$. Therefore, the strawberry should be studied to determine if oral insulin administration is a viable option for people with diabetes. According to Mendel's rules of inheritance, if a gene is delivered into the nucleus of a plant cell, at least one-fourth of the plant will be non-transgenic in the following generation $\mathbf{9 6}$. However, the presence of runners in strawberry plants, which are clones of the mother plant, allows each generation to have a mother plant ${ }^{95}$. Because of these qualities, the strawberry plant is a suitable expression system for human proinsulin gene transformation and recombinant protein production.

In a recent study, Tavizi et al. infected strawberry explants (leaves, petiole, and buds) with A. rhizogenes and $A$. tumefaciens that contained insulin-producing genes. The hairy roots that grew as a result of the treatment with $A$. rhizogenes were subcultured in a bioreactor for several days, while the explants infected with A. tumefaciens were micropropagated. The transmission and expression of the insulin genes in the hairy roots and regenerated plants were analyzed through PCR, RT-PCR, and ELISA. Additionally, the proinsulin was purified from the transgenic plants and hairy roots and injected into diabetic rats. $60 \mathrm{ng}$ of the purified insulin was able to significantly reduce the blood sugar levels in these rats ${ }^{\mathbf{9 5}}$.

\section{ROLE OF STEM CELLS IN THE TREATMENT OF DIABETES}

Stem cells are specialized cells that eventually develop into the tissues and organs of the body. Throughout its life, the body relies on stem cells to repair damaged tissues and cells that are lost regularly, as they can self-renew and differentiate. Embryonic stem cells (ESCs), mesenchymal stem cells (MSCs), and induced pluripotent stem cells (iPSCs) have all been developed into insulin-producing cells (Figure 6) ${ }^{2,97}$.

\section{Embryonic Stem Cells (ESCs)}

ESCs can develop into endoderm, mesoderm, and ectoderm cells and are extracted from blastocysts. When ESCs are transplanted into diabetic mice, they can develop into insulin-producing cells, which can release insulin in response to glucose stimulation and restore proper blood glucose levels ${ }^{\mathbf{9 8}, 99}$. Human ESCs can also be differentiated into endocrine cells, however, this carries the risk of promoting tumor formation 100 .

\section{Induced Pluripotent Stem Cells (iPSCs)}

Like ESCs, iPSCs have an indefinite capacity for selfrenewal and the ability to differentiate into a wide range of cell types. Undifferentiated iPSCs can be maintained as cell lines, which holds tremendous potential for disease modeling and the development of autologous cell therapies ${ }^{101}$. iPSCs generated from mouse skin fibroblasts were able to develop into $\beta$-like cells, comparable to the natural, endogenous insulinsecreting cells, and helped diabetic mice regulate hyperglycemia ${ }^{102}$. Human ESCs and iPSCs have been developed into mature pancreatic cells capable of secreting insulin and C-peptide ${ }^{103}$. Insulin-producing cells were also grown in vitro from iPSCs using small chemicals and growth factors ${ }^{104}$.

\section{Mesenchymal Stem Cells (MSCs)}

MSCs can be extracted from adipose tissue, mobilized peripheral blood, fetal liver, periodontal ligament, umbilical cord blood, placenta, fetal lung, dental pulp, umbilical cord, synovial membrane, endometrium, compact bone, trabecular and dental pulp, synovial membrane, endometrium, periodontal ligament, and trabecular and compact bone ${ }^{105}$. MSCs can differentiate into mesodermal, endodermal, and even ectodermal cells when cultured under the right circumstances ${ }^{106}$. They can secrete growth factors and immunoprotective cytokines during transplantation ${ }^{107}$. MSCs have also been injected directly into the pancreas as niche-providing cells, which helped relieve diabetic symptoms in animal models by improving metabolic regulation, counteracting autoimmunity, boosting islet engraftment and survival, and acting as 
a source of growth factors and cytokines ${ }^{108}$. MSC injections enhance pancreatic function while also alleviating symptoms such as diabetic foot, nephropathy, and neuropathy. Although MSCs appear to have a significant impact, it is more likely to be a niche effect than genuine regeneration ${ }^{109}$.

\section{Bone Marrow-Derived Mesenchymal Stem Cells}

Human bone marrow (BM)-derived MSCs can be maintained in vitro for up to 44 weeks without losing their morphological, phenotypical, functional, or karyotype features ${ }^{110}$. MSCs from the BM suppress the immunological response of $\mathrm{T}$ cells towards freshly generated $\beta$ cells $^{111}$. As a result, stem cell therapy may be the most effective treatment for patients with type 1 diabetes. Stem cells migrate to the injured area, develop, and initiate structural and functional repair, which aids in the treatment of diabetes and the normalization of insulin levels. Mouse bone marrow cells developed into functional $\beta$ cells in an in vivo experiment $^{112}$. In another investigation, iPSCs from BMMSC rats were shown to cure chronic hyperglycemia in diabetic rats.

\section{Adipose-Derived Stromal Cells (ADSCs)}

Adipose-derived stromal cells (ADSCs), also known as adipose tissues isolated from human lipoaspirates, can be obtained in high quantities and have differentiation capabilities comparable to BM-MSCs. When $\mathrm{AD}-\mathrm{MSC}$ s were grown in a fibroblast growth factorcontaining medium, they produced markers such as Isl1 mRNA, which are required for the formation of pancreatic islet cells ${ }^{113}$. Several studies have shown that AD-MSCs from the mouse epididymis can develop into cells that express PDX1, Ngn3, NeuroD, Pax4, Glut2, and produce insulin and C-peptide ${ }^{114}$. After 38 days of co-culture with islet cells, AD-MSCs were shown to be differentiated into iPSCs ${ }^{115}$. Compared to islet transplants alone or co-transplantation of islets and differentiated BM-MSCs, combining differentiated AD-MSCs and islet cells resulted in better diabetes recovery ${ }^{116}$.

\section{Human Umbilical Cord Blood-Derived Mes- enchymal Stem Cells}

MSCs from umbilical cord blood and unrestricted somatic stem cells from hUCB can develop into iPSCs with the same cell markers and characteristics as MAPCs (multipotent adult progenitor cells) ${ }^{117}$. After incubation in a medium supplied with no particular cytokines or growth factors besides fetal calf serum, UCB cells express genes necessary for differentiation into pancreatic endocrine tissue, including Isl1, PDX1, Pax4, and Ngn3 ${ }^{113}$. In vitro and in vivo, insulin and the $\mathrm{C}$-peptide were released by iPSCs generated from UCB-MSCs in response to a glucose challenge. After intravenous injection of hUCBMSCs into 25 NOD type 1 diabetic mice with insulitis, glycemic profiles improved along with histological improvements in the islets ${ }^{118}$. UCB-MSCs are widely accessible, have minimal risk of immunological rejection, and show improved capabilities for growth and differentiation into iPSCs, making them a viable choice for the treatment of diabetes.

\section{Comparative Analysis}

Humanized gene expression is better in eukaryotic systems than in prokaryotic systems. The human insulin gene, which is eukaryotic, cannot be immediately transferred to a prokaryotic expression system, because the gene contains introns that must be spliced before translation, followed by PTMs to create the active insulin product. Instead, cDNA of the desired gene is created and then injected into a prokaryotic cell. E.coli has historically been the favored prokaryotic expression system for large-scale recombinant protein production because of its ease of genetic modification, cost-effectiveness, and high growth and recombinant protein synthesis rates $\mathbf{1 1 9 , 1 2 0}$. However, this expression system comprises a large number of uncommon codons and has a high incidence of translational mistakes such as amino acid substitutions, premature translation termination, and frame-shift mutations. In the case of therapeutic proteins like insulin, such mistakes might degrade the quality, causing an immunogenic reaction in humans ${ }^{121}$. PTMs, loss of plasmids, antibiotic properties, and the downstream procedures to extract the required proteins from chaperones are some of the drawbacks of employing an E. coli expression method.

Humanized yeast expression systems, which use single-celled organisms with eukaryotic posttranslational modification processes, can be employed to overcome the aforementioned constraints. On a large scale, yeast can be readily maintained using a basic medium. Among yeast species, $S$. cerevisiae plays a crucial role, particularly in the production of proinsulin analogs. With naturally occurring plasmids, it has been described to have strong related promoters. It only produces a few proteins. Regardless of its high copy number and the presence of LUE2, yeast episomal plasmids are most commonly utilized for manufacturing ${ }^{\mathbf{1 2 2}}$. 
S. cerevisiae is used to produce Insulin Aspart, a fast-acting insulin derivative. $P$. pastoris, on the other hand, is a better choice for industrial-scale production due to its plasmid degradation and lesser extent of hyperglycosylation. In both bacterial and yeast expression methods, the total space-time yield is similar, although yeast, particularly $P$. pastoris, is more appropriate ${ }^{123}$.

As transgenic plants do not contain human diseases, they are thought to be a safer expression method for human insulin. A. thaliana seeds, tobacco and lettuce plant leaves, and strawberry root hairs are among the transgenic plants being studied for use in proinsulin production. Physiologically active insulin can be readily isolated from subcellular oil bodies of $A$. thaliana seeds using liquid-phase chromatography ${ }^{124}$. At a larger scale, enzymatic purification can be employed. The shockability and low cost of seeds as a bioreactor are the two most essential advantages. However, difficulties with protein stability remain a key concern when utilizing plant expression systems. To prevent problems like these, tobacco and lettuce plant leaves were chosen as proinsulin bioreactors $^{125}$. In their global usage, tobacco provides protection against food-chain contamination, while lettuce does not ${ }^{126}$. However, the chloroplastbased expression mechanism utilized in both plants has chloroplast glucan interference, nonhuman glycosylation, and may require PTMs. As a result, before employing such expression methods, changes to the production method are necessary ${ }^{127}$. Strawberry is another intriguing plant for proinsulin synthesis, and its root hairs are being studied as a bioreactor. It is, so far, the safest option, as there is no gene escape ${ }^{\mathbf{1 2 8}}$. Unfortunately, it can induce allergic responses in people when consumed orally.

ESCs are a popular target for researchers because they are produced from unused or unfertilized embryos at in vitro fertilization clinics, but there are few limitations in utilizing these cells. They should only be utilized for clinical studies with the prior consent of the donor. However, in the majority of cases, cells from the embryo are acquired by destroying the embryo, which raises ethical concerns regarding the origin of life and the right to annihilate the embryo ${ }^{129}$. Human ESCs can be differentiated into endocrine cells, but they may also promote tumor growth ${ }^{\mathbf{1 3 0}}$.

The lack of ethical issues and minimal probability of teratoma development are two advantages of utilizing iPSCs ${ }^{131}$. The most common method for transforming somatic cells into iPSCs is to use viral transfection of transcription factors. The use of harmful genomes, which can cause mutations and affect normal iPSC function, differentiation ability, and tumorigenesis, is an important drawback of this technology ${ }^{131}$. Similarly, MSCs seldom differentiate spontaneously in the host tissue. Thus, their therapeutic utility relies on the capacity to regulate their in vivo differentiation into functional cells with high efficiency and purity ${ }^{132}$. Additionally, MSCs can develop into undesirable mesenchymal lineages, which might restrict their therapeutic effectiveness ${ }^{133}$. A comparative analysis of the different expression systems that have been discussed for insulin production is provided in Table 1. 
Table 1: Comparative analysis of different expression systems used for production of human insulin

\begin{tabular}{|c|c|c|c|c|c|}
\hline ExpressionSystems & Advantage & $\begin{array}{l}\text { Year } \\
\text { of FDA } \\
\text { Approval }\end{array}$ & Limitations & Advancements & References \\
\hline \multicolumn{6}{|c|}{ Prokaryotic Expression System } \\
\hline Escherichiacoli & $\begin{array}{l}\text { Versatility and cost-effectiveness for large } \\
\text { scale production }\end{array}$ & $\begin{array}{l}\text { US FDA in } \\
1982\end{array}$ & $\begin{array}{l}\text { Plasmid loss, high probability of } \\
\text { translation errors which can cause } \\
\text { adverse immunological responses } \\
\text { in human }\end{array}$ & $\begin{array}{l}\text { Colony PCR strategies for simi- } \\
\text { larity verification, strain modifi- } \\
\text { cations, codon optimizations and } \\
\text { addition of chaperones }\end{array}$ & 45,59 \\
\hline \multicolumn{6}{|l|}{ Yeast Expression System } \\
\hline Saccharomyces cerevisiae & $\begin{array}{l}\text { Eukaryotic model systemwhich enables the } \\
\text { quality production and proper folding. }\end{array}$ & $\begin{array}{l}\text { US FDA in } \\
2001\end{array}$ & $\begin{array}{l}\text { Plasmid degradation and Hyper- } \\
\text { glycosylation on large scale. } \\
\text { Time consuming purification } \\
\text { methods. }\end{array}$ & $\begin{array}{l}\text { Modification in recombinant se- } \\
\text { quence of B chain cDNA to pro- } \\
\text { long the insulin effect duration. }\end{array}$ & 121 \\
\hline Pichia pastoris & $\begin{array}{l}\text { High cell density of Methylotrophic yeast } \\
\text { with methanol-inducible } \\
\text { alcohol oxidase-1 (AOX-1)promoter, do } \\
\text { not hyper glycosylate insulin }\end{array}$ & $\begin{array}{l}\text { US FDA in } \\
2009\end{array}$ & $\begin{array}{l}\text { High mannose structures and gly- } \\
\text { cosylation heterogeneity can cause } \\
\text { batch-to-batch variation }\end{array}$ & $\begin{array}{l}\text { Engineered strains for higher } \\
\text { secretion levels, AOX1-based } \\
\text { methanol-free protein manufac- } \\
\text { ture, modified } \\
\text { N-glycosylation machinery }\end{array}$ & 122,123 \\
\hline \multicolumn{6}{|l|}{ Transgenic Plants } \\
\hline Arabidopsis thaliana & $\begin{array}{l}\text { Large amount of seed generation in } 6 \\
\text { weeks, easy purification of oil bodies, no } \\
\text { human pathogen, shockable }\end{array}$ & $\begin{array}{l}\text { Approval } \\
\text { required }\end{array}$ & $\begin{array}{l}\text { Protein stability issues } \\
\text { Inappropriate containment strate- } \\
\text { gies }\end{array}$ & $\begin{array}{l}\text { Finding tissue-specific promoters } \\
\text { to avoid toxicity }\end{array}$ & 124 \\
\hline Tobacco & $\begin{array}{l}\text { High number of leaves yield contains } \\
\text { proinsulin, high purity protein with min- } \\
\text { imal PTMs requirement, less transgene } \\
\text { containment. }\end{array}$ & & $\begin{array}{l}\text { Chloroplast glycoproteins interfer- } \\
\text { ence }\end{array}$ & $\begin{array}{l}\text { Transformed chloroplast, CTB- } \\
\text { insulin fusion }\end{array}$ & 125,126 \\
\hline Lettuce & $\begin{array}{l}\text { Long term stability in leaves, more leaf pro- } \\
\text { tein yield then tobacco plant }\end{array}$ & & $\begin{array}{l}\text { Lack of regulatory approval due } \\
\text { to food-chain contamination, Im- } \\
\text { proper glycosylation }\end{array}$ & Transformed chloroplast & 126 \\
\hline
\end{tabular}




\begin{tabular}{|c|c|c|c|c|c|}
\hline \multicolumn{6}{|l|}{ Table 1 continued } \\
\hline ExpressionSystems & Advantage & $\begin{array}{l}\text { Year } \\
\text { of FDA } \\
\text { Approval }\end{array}$ & Limitations & Advancements & References \\
\hline Strawberry & $\begin{array}{l}\text { Oral consumption, using hairy roots as } \\
\text { bioreactor }\end{array}$ & & $\begin{array}{l}\text { lack of regulatory approval, un- } \\
\text { wanted allergic reactions }\end{array}$ & No gene escape & 127,128 \\
\hline \multicolumn{6}{|l|}{ Stem cells } \\
\hline $\begin{array}{l}\text { Embryonic stem cells } \\
\text { (ESC) }\end{array}$ & Can differentiate into any cell type & $\begin{array}{l}\text { Approval } \\
\text { required }\end{array}$ & $\begin{array}{l}\text { Ethical issues, Chances of immune } \\
\text { rejection, genetic instability, tera- } \\
\text { tocarcinomas formation }\end{array}$ & $\begin{array}{l}\text { Generation of pancreatic progeni- } \\
\text { tor cells through ESCs }\end{array}$ & $134-137$ \\
\hline $\begin{array}{l}\text { Induced pluripotent stem } \\
\text { cells (iPSCs) }\end{array}$ & $\begin{array}{l}\text { No ethical issues, less immune rejection } \\
\text { chances, variable sources to derive iPSCs, } \\
\text { can differentiate into variety of cell types }\end{array}$ & & $\begin{array}{l}\text { Require reteroviruses to generate } \\
\text { iPSCs, chances of cancer formation }\end{array}$ & $\begin{array}{l}\text { Use of non-viral reprogramming } \\
\text { factors for generation of iPSCs }\end{array}$ & 138-140 \\
\hline $\begin{array}{l}\text { Bone Marrow derived } \\
\text { Mesenchymal stem cells } \\
\text { (BM-MSCs) }\end{array}$ & $\begin{array}{l}\text { Easy isolation, no ethical issues, can differ- } \\
\text { entiate in variety of cell types }\end{array}$ & & $\begin{array}{l}\text { Minimal differentiation potential, } \\
\text { differentiate into unwanted mes- } \\
\text { enchymal lineages }\end{array}$ & $\begin{array}{l}\text { Use of nanotechnology and gene } \\
\text { regulation enhanced the differen- } \\
\text { tiation and proliferation ability of } \\
\text { MSCs }\end{array}$ & 132,141 \\
\hline $\begin{array}{l}\text { Adipose-derived } \\
\text { enchymal Stem cells } \\
\text { (AD-MSCs) }\end{array}$ & $\begin{array}{l}\text { No ethical issues, different isolation } \\
\text { sources, high histocompatibility and low } \\
\text { immune rejection }\end{array}$ & & $\begin{array}{l}\text { Low multipotency and proliferative } \\
\text { ability, genetic instability, apoptosis } \\
\text { occurs in newly produced cells }\end{array}$ & & 142,143 \\
\hline $\begin{array}{l}\text { Human Placenta derived } \\
\text { Mesenchymal stem cells } \\
\text { (HP-MSCs) }\end{array}$ & $\begin{array}{l}\text { High proliferative and differentiation rate, } \\
\text { Ease in extraction }\end{array}$ & & & $\begin{array}{l}\text { Use of nanotechnology to pro- } \\
\text { mote drug delivery and detection } \\
\text { of transplanted cells }\end{array}$ & $144-146$ \\
\hline $\begin{array}{l}\text { Human Umbilical Cord } \\
\text { derived Mesenchymal } \\
\text { stem cells (HUC-MSCs) }\end{array}$ & $\begin{array}{l}\text { High proliferative and differentiation } \\
\text { rate, } 10 \text { times more stem cells than } \\
\text { those collected from bone marrow, Anti- } \\
\text { inflammatory properties, anti-fibrotic } \\
\text { potential, low risk of immune rejection }\end{array}$ & & $\begin{array}{l}\text { Limited cells can be isolated for } \\
\text { once from umbilical cord, less } \\
\text { banks for storage of umbilical } \\
\text { cords, require more time to graft }\end{array}$ & & $132,147,148$ \\
\hline
\end{tabular}




\section{CONCLUSIONS AND FUTURE DIRECTIONS}

The two conventional methods of producing insulin by recombinant technology are the proinsulin method and the two-chain method. The proinsulin method was developed more recently and is more reliable because it involves fewer steps than the two-chain method, making it effective and cost-efficient. Bacterial and yeast expression systems are generally preferred for commercial production, but novel organisms and transgenic plants have recently been introduced. In E. coli and S. cerevisiae, the C-peptide of proinsulin is absent, which can be dealt with by certain genetic modifications in existing expression systems or by using new transgenic organisms like P. pastoris, A. thaliana, tobacco, strawberry, or lettuce. Additionally, transgenic plants can provide a higher level of protein expression. Even though human MSCs could be differentiated into functional pancreatic cells in vitro, the rate of trans-differentiation is limited, and the length of functional maintenance in vivo is challenging to assess. Considering the lack of defined protocols for the growth and production of insulinsecreting cells, clinical results are inconsistent. The use of novel approaches such as nanotechnology, signaling hormones, non-viral programming, or gene regulation of different types of stem cells can be utilized to develop insulin-producing cells that can serve as a useful treatment option for patients with diabetes. To achieve long-term stability, low-cost technologies should be promoted. Additionally, oral delivery of insulin is a safer method.

\section{ABBREVIATIONS}

A. rhizogenes: Agrobacterium rhizogenes

A. thaliana: Arabidopsis thaliana

A. tumefaciens: Agrobacterium tumefaciens

AD-MSCs: Adipose-derived Mesenchymal Stem cells AOX-1: Alcohol oxidase-1 promoter

BM-MSCs: Bone Marrow derived Mesenchymal stem

cells

CNBr: Cyanogen bromide

CNS: Central nervous system

DTT: Dithiothreitol

E. coli: Escherichia coli

ESCs: Embryonic stem cells

GI: Gastrointestinal tract
GSH: Glutathione

HP-MSCs: Human Placenta derived Mesenchymal stem cells

HUC-MSCs: Human Umbilical Cord derived Mesenchymal stem cells

IP: Insulin precursors

iPSCs: Induced pluripotent stem cells

LB: Luria Broth

P. pastoris: Pichia pastoris

PSI: Pounds per square inch

PTMs: Post-translational modifications

RE: Restriction enzyme

Rpm: Revolutions per minute

S. cerevisiae: Saccharomyces cerevisiae

STR: Stirred tank reactor

T1DM patients: Type 1 Diabetes mellitus patients

\section{ACKNOWLEDGMENTS}

The authors are thankful to the team of Big Bio for their support.

\section{AUTHOR'S CONTRIBUTIONS}

All the authors contributed equally in manuscript writing. J. Alyas, A. Rafiq, H. Amir and T. Sajid conceptualized study and wrote introduction of the manuscript. S. U. Khan, T. Sultana, A. Hameed and I. Ahmad, wrote about the insulin production and revised it critically. A. Ali and A. Kazmi designed and modified the figures, wrote manuscript and approved the final version of the manuscript for submission.

\section{FUNDING}

None.

\section{AVAILABILITY OF DATA AND MATERIALS}

Not applicable.

\section{ETHICS APPROVAL AND CONSENT TO PARTICIPATE}

Not applicable.

\section{CONSENT FOR PUBLICATION}

Not applicable.

\section{COMPETING INTERESTS}

The authors declare that they have no competing interests. 


\section{REFERENCES}

1. Gasco V, Ferrero A, Bisceglia A, Prencipe N, Cambria V, Bioletto F. The Cut-off Limits of Growth Hormone Response to the Insulin Tolerance Test Related to Body Mass Index for the Diagnosis of Adult Growth Hormone Deficiency. Neuroendocrinology. 2021;111(5):442-50. PMID: 32335555. Available from: 10.1159/000508103.

2. Kazmi A, Kazmi A, Muhammad W, Azhar M. Mesenchymal stem cells transplantation reduces diabetic nephropathy. Progress in Stem Cell. 2019;6(1):260-8. Available from: 10.15419/psc.v6i1.403.

3. Angi A, Chiarelli F. Obesity and Diabetes: A Sword of Damocles for Future Generations. Biomedicines. 2020;8(11):478. PMID: 33171922. Available from: 10.3390/ biomedicines8110478.

4. Mahgoub WME, Ali IA. Insulin; from Genome to Metabolome. East African Scholars Journal of Biotechnology and Genetics. 2019;1(1):14-17.

5. Ruud J, Steculorum SM, Brüning JC. Neuronal control of peripheral insulin sensitivity and glucose metabolism. Nature Communications. 2017;8(1):15259. PMID: 28469281. Available from: 10.1038/ncomms15259.

6. Qaid MM, Abdelrahman MM. Role of insulin and other related hormones in energy metabolism: A review. Cogent Food \& Agriculture. 2016;2(1):1267691. Available from: 10. 1080/23311932.2016.1267691.

7. Cantley J, Ashcroft FM. Q\&A: insulin secretion and type 2 diabetes: why do $\beta$-cells fail? BMC Biology. 2015;13(1):1-7. PMID: 25555396. Available from: 10.1186/s12915-015-01406.

8. Lewis GF, Brubaker PL. The discovery of insulin revisited: lessons for the modern era. The Journal of Clinical Investigation. 2021;131(1):142239. PMID: 33393501. Available from: 10.1172/JCI142239.

9. Stansfield WD. The discovery of insulin: a case study of scientific methodology. The American Biology Teacher. 2012;74(1):10-4. Available from: 10.1525/abt.2012.74.1.4.

10. Jorgensen-Earp CR, Jorgensen DD. To Fly Under Borrowed Colours: Insulin Discovery Accounts, Scientific Credit, and the Nobel Prize. Rhetoric \& Public Affairs. 2020;23(1):1-45. Available from: 10.14321/rhetpublaffa.23.1.0001.

11. Hegele RA, Maltman GM. Insulin's centenary: the birth of an idea. The Lancet Diabetes \& Endocrinology. 2020;8(12):9717. PMID: 33129375 . Available from: $10.1016 /$ S2213-8587(20) 30337-5.

12. Vecchio I, Tornali C, Bragazzi NL, Martini M. The discovery of insulin: an important milestone in the history of medicine. Frontiers in Endocrinology (Lausanne). 2018;9:613. PMID: 30405529. Available from: 10.3389/fendo.2018.00613.

13. Moroder L, Musiol HJ. Insulin from its discovery to the industrial synthesis of modern insulin analogues. Angewandte Chemie International Edition in English. 2017;56(36):1065669. PMID: 28548452. Available from: 10.1002/anie.201702493.

14. Beischer W. Proinsulin and C-peptide in humans. Hormones in normal and abnormal human tissues. vol. Volume 3. De Gruyter; 2019. Available from: 10.1515/9783111582122-003.

15. Weiss M, Steiner DF, Philipson LH. Insulin Biosynthesis, Secretion, Structure, and Structure-Activity Relationships. [Updated 2014 Feb 1]. In: Feingold KR, Anawalt B, Boyce A, et al., editors. Endotext [Internet]. South Dartmouth (MA): MDText.com, Inc.; 2000-. Available from: https://www.ncbi.nIm. nih.gov/books/NBK279029/; 2015.

16. Gan WJ, Do OH, Cottle L, Ma W, Kosobrodova E, CooperWhite J, et al. Local integrin activation in pancreatic $\beta$ cells targets insulin secretion to the vasculature. Cell reports. 2018;24(11):2819-26.

17. Ruzittu S. Molecular mechanisms underlying pancreatic identity and plasticity in mammalian species. Doctoral Thesis. Berlin, Germany; 2020. Available from: http://dx.doi.org/ $10.17169 /$ refubium-27558.
18. Matteucci E, Giampietro O, Covolan V, Giustarini D, Fanti $P$, Rossi R. Insulin administration: present strategies and future directions for a noninvasive (possibly more physiological) delivery. Drug Design, Development and Therapy. 2015;9:3109-18. PMID: 26124635. Available from: 10.2147/ DDDT.S79322.

19. Jansson L, Barbu A, Bodin B, Drott CJ, Espes D, Gao X. Pancreatic islet blood flow and its measurement. Upsala Journal of Medical Sciences. 2016;121(2):81-95. PMID: 27124642. Available from: 10.3109/03009734.2016.1164769.

20. Chen Z, Wang J, Sun W, Archibong E, Kahkoska AR, Zhang $X$. Synthetic beta cells for fusion-mediated dynamic insulin secretion. Nature Chemical Biology. 2018;14(1):86-93. PMID: 29083418. Available from: $10.1038 /$ nchembio.2511.

21. Campbell JE, Newgard CB. Mechanisms controlling pancreatic islet cell function in insulin secretion. Nature Reviews Molecular Cell Biology. 2021;22(2):142-58. PMID: 33398164. Available from: 10.1038/s41580-020-00317-7.

22. Cheng V, Cottrell P, Johnson JM, Sanal A. Endocrine System (October 18, 2018). Available at SSRN: https://ssrn.com/ab stract=3309237 or http://dx.doi.org/10.2139/ssrn.3309237 . 2018;p. 3309237.

23. Frayn KN, Arner $\mathrm{P}, \mathrm{Yki}$-Järvinen $\mathrm{H}, \mathrm{Yki}$-Järvinen $\mathrm{H}$. Fatty acid metabolism in adipose tissue, muscle and liver in health and disease. Essays in Biochemistry. 2006;42:89-103. PMID: 17144882. Available from: 10.1042/bse0420089.

24. Sayem AS, Arya A, Karimian H, Krishnasamy N, Hasamnis AA, Hossain CF. Action of phytochemicals on insulin signaling pathways accelerating glucose transporter (GLUT4) protein translocation. Molecules (Basel, Switzerland). 2018;23(2):258. PMID: 29382104. Available from: $10.3390 /$ molecules 23020258 .

25. Bliss M. The discovery of insulin. University of Toronto Press; 2019.

26. Animaw W, Seyoum Y. Increasing prevalence of diabetes mellitus in a developing country and its related factors. PLoS One. 2017;12(11):e0187670. PMID: 29112962. Available from: 10.1371/journal.pone.0187670.

27. Quianzon CC, Cheikh I. History of insulin. Journal of Community Hospital Internal Medicine Perspectives. 2012;2(2):18701. PMID: 23882369. Available from: 10.3402/ jchimp.v2i2.18701.

28. Chinnaboina GK, Sudhakar A, Verma R, Sharma P, Shrivastava B. A Review on Diabetes Mellitus: Current Update on Management and Treatment. Asian Pacific Journal Health Science. 2018;53(3):67-82. Available from: 10.21276/apjhs.2018. 5.3.20.

29. Karamitsos DT. The story of insulin discovery. Diabetes Research and Clinical Practice. 2011;93:2-8. PMID: 21864746. Available from: 10.1016/S0168-8227(11)70007-9.

30. Wellington A. Leonard Thompson 'ever remembered': the first person to receive insulin. Journal of Medical Biography. 2020;2020:0967772020974355. Available from: 10 . 1177/0967772020974355.

31. King KM. A history of insulin: from discovery to modern alternatives. British Journal of Nursing (Mark Allen Publishing). 2003;12(19):1137-41. PMID: 14593261. Available from: 10.12968/bjon.2003.12.19.11801.

32. Ghazavi MK, Johnston GA. Insulin allergy. Clinics in Dermatology. 2011;29(3):300-5. PMID: 21496738. Available from: 10.1016/j.clindermatol.2010.11.009.

33. Hughes SS. Genentech: the beginnings of biotech. University of Chicago Press; 2011. Available from: 10.7208/chicago/ 9780226359205.001.0001.

34. Riggs AD. Making, Cloning, and the Expression of Human Insulin Genes in Bacteria: The Path to Humulin. Endocrine Reviews. 2021;42(3):374-80. PMID: 33340315. Available from: $10.1210 /$ endrev/bnaa 029 .

35. Wong DW. Microbial production of recombinant human insulin. The ABCs of Gene Cloning. Springer; 2018. Available from: 10.1007/978-3-319-77982-9_17. 
36. Sandow J, Landgraf W, Becker R, Seipke G. Equivalent recombinant human insulin preparations and their place in therapy. European Endocrinology. 2015;11(1):10-6. PMID: 29632560. Available from: 10.17925/EE.2015.11.01.10.

37. Baeshen NA, Baeshen MN, Sheikh A, Bora RS, Ahmed MM, Ramadan HA. Cell factories for insulin production. Microbial Cell Factories. 2014;13(1):141. PMID: 25270715. Available from: 10.1186/s12934-014-0141-0.

38. Ranjbari J, Babaeipour V, Vahidi H, Moghimi H, Mofid MR, Namvaran MM. Enhanced production of insulin-like growth factor I protein in Escherichia coli by optimization of five key factors. Iranian journal of pharmaceutical research. Iranian Journal of Pharmaceutical Research. 2015;14(3):907-17. PMID: 26330880.

39. Jing J, Chen Y, Sheng L, Wu M. Optimized production of insulin variant, a recombinant platelet aggregation inhibitor, by high cell-density fermentation of recombinant Escherichia coli. Protein Expression and Purification. 2018;152:7-12. PMID: 30033357. Available from: 10.1016/j. pep.2018.07.001.

40. Yu R, Li X, Yang J, Wu W. Optimized production of insulin variant, a recombinant platelet aggregation inhibitor, by high cell-density fermentation of recombinant Escherichia coli Protein Expr Purif. 2004;152:7-12. PMID: 30033357. Available from: 10.1016/j.pep.2018.07.001.

41. Maschke A, Calí N, Appel B, Kiermaier J, Blunk T, Göpferich A. Micronization of insulin by high pressure homogenization. Pharmaceutical Research. 2006;23(9):2220-9. PMID: 16906458. Available from: 10.1007/s11095-006-9019-0.

42. Middelberg AP, O'Neill BK, Bogle IDL, Snoswell MA. A novel technique for the measurement of disruption in highpressure homogenization: studies on $\mathrm{E}$. coli containing recombinant inclusion bodies. Biotechnology and Bioengineering. 1991;38(4):363-70. PMID: 18600772. Available from: 10.1002/bit.260380406.

43. Berlec A, Strukelj B. Current state and recent advances in biopharmaceutical production in Escherichia coli, yeasts and mammalian cells. Journal of Industrial Microbiology \& Biotechnology. 2013;40(3-4):257-74. PMID: 23385853. Available from: $10.1007 / \mathrm{s} 10295-013-1235-0$.

44. Liu F, Zaykov AN, Levy JJ, DiMarchi RD, Mayer JP. Chemical synthesis of peptides within the insulin superfamily. Journal of Peptide Science. 2016;22(5):260-70. PMID: 26910514. Available from: $10.1002 / \mathrm{psc} .2863$.

45. Govender K, Naicker T, Lin J, Baijnath S, Chuturgoon AA, Abdul NS. A novel and more efficient biosynthesis approach for human insulin production in Escherichia coli (E. coli). AMB Express. 2020;10(1):43. PMID: 32152803. Available from: 10.1186/s13568-020-00969-w.

46. Zieliński $M$, Romanik-Chruścielewska A, Mikiewicz $D$, Lukasiewicz N, lowska IS, Antosik J, et al. Expression and purification of recombinant human insulin from E. coli 20 strain. Protein Expression and Purification. 2019;157:63-9. PMID: 30735706. Available from: 10.1016/j.pep.2019.02.002.

47. Yuan J, Zhou H, Yang Y, Li W, Wan Y, Wang L. Refolding and simultaneous purification of recombinant human proinsulin from inclusion bodies on protein-folding liquidchromatography columns. Biomedical Chromatography. 2015;29(5):777-82. PMID: 25378200. Available from: 10 $1002 /$ bmc. 3358

48. Kim CK, Lee SB, Son YJ. Large-scale refolding and enzyme reaction of human preproinsulin for production of human insulin. Journal of Microbiology and Biotechnology. 2015;25(10):1742-50. PMID: 26139616. Available from: 10.4014/jmb.1504.04062.

49. Min CK, Son YJ, Kim CK, Park SJ, Lee JW. Increased expression, folding and enzyme reaction rate of recombinant human insulin by selecting appropriate leader peptide. Journal of Biotechnology. 2011;151(4):350-6. PMID: 21219941. Available from: 10.1016/j.jbiotec.2010.12.023.

50. Mbanya JC, Sandow J, Landgraf W, Owens DR. Recombinant Human Insulin in Global Diabetes Management - Focus on
Clinical Efficacy. European Endocrinology. 2017;13(1):21-5. PMID: 29632602. Available from: 10.17925/EE.2017.13.01.21.

51. Nilsson J, Jonasson $P$, Samuelsson $E$, Staahl S, Uhlén M. Integrated production of human insulin and its C-peptide. Journal of Biotechnology. 1996;48(3):241-50. PMID: 8862001. Available from: 10.1016/0168-1656(96)01514-3.

52. Ladisch MR, Kohlmann KL. Recombinant human insulin Biotechnology Progress. 1992;8(6):469-78. PMID: 1369033. Available from: 10.1021/bp00018a001.

53. Newsome CL. Investigation into the Biological Importance and Function of Proinsulin C-Peptide (2015). Theses, Dissertations and Capstones. 958; 2015. Available from: https: $/ / \mathrm{mds}$.marshall.edu/etd/958.

54. Slattery D, Amiel SA, Choudhary P. Optimal prandial timing of bolus insulin in diabetes management: a review. Diabetic Medicine. 2018;35(3):306-16. PMID: 29044708. Available from: $10.1111 /$ dme. 13525

55. Niloy KK. Injectable Systems for Long-Lasting Insulin Therapy (2019). Theses and Dissertations (ETD). Paper 487. Available from: 10.21007/etd.cghs.2019.0479.

56. Gutka H, Prasad K. Case Studies and Examples of Biopharmaceutical Modalities Processed by Bulk Crystallization or Bulk Freeze-Drying. Lyophilized Biologics and Vaccines. Springer; 2015. Available from: 10.1007/978-1-4939-2383-0_14.

57. Chausmer AB. Zinc, insulin and diabetes. Journal of the American College of Nutrition. 1998;17(2):109-15. PMID: 9550453. Available from: 10.1080/07315724.1998.10718735.

58. Frost GI, Bilinsky I, Vaughn D, Sugarman B. Super Fast-Acting Insulin Compositions. Google Patents; 2014.

59. Dave S. Mesenchymal stem cells derived in vitro transdifferentiated insulin-producing cells: A new approach to treat type 1 diabetes. Advanced Biomedical Research. 2014;3(1):266. PMID: 25625105. Available from: 10.4103/ 2277-9175.148247.

60. Begg A. Insulin therapy: a pocket guide. Taylor \& Francis; 2013.

61. Dingermann T. Recombinant therapeutic proteins: production platforms and challenges. Biotechnology Journal. 2008;3(1):90-7. PMID: 18041103. Available from: 10.1002/ biot.200700214.

62. Piri H, Kazemi B, Rezaei M, Bandehpour M, Khodadadi I, Hassanzadeh $\mathrm{T}$. Construction of plasmid insulin gene vector containing metallothionein IIA (pcDNAMTChins) and carbohydrate response element (ChoRE), and its expression in NIH3T3 cell line. International Journal of Endocrinology and Metabolism. 2012;10(3):543-7. PMID: 23843817. Available from: 10.5812/ijem. 4540 .

63. Wild S, Roglic G, Green A, Sicree R, King H. Global prevalence of diabetes: estimates for the year 2000 and projections for 2030. Diabetes Care. 2004;27(5):1047-53. PMID: 15111519. Available from: 10.2337/diacare.27.5.1047.

64. Walsh G. Therapeutic insulins and their large-scale manufacture. Applied Microbiology and Biotechnology. 2005;67(2):151-9. PMID: 15580495. Available from: 10.1007/ s00253-004-1809-x.

65. Akbarian M, Yousefi R. Human $\alpha$ B-crystallin as fusion protein and molecular chaperone increases the expression and folding efficiency of recombinant insulin. PLoS One. 2018;13(10):e0206169. PMID: 30339677. Available from: 10.1371/journal.pone.0206169.

66. Cowley DJ, Mackin RB. Expression, purification and characterization of recombinant human proinsulin. FEBS Letters. 1997;402(2-3):124-30. PMID: 9037180. Available from: 10.1016/S0014-5793(96)01511-6.

67. Zhao M, Jiang Y. Great expectations and challenges of artificial intelligence in the screening of diabetic retinopathy. Nature Publishing Group; 2020. Available from: 10.1038/ s41433-019-0629-2.

68. Redwan EM, Linjawi MH, Uversky VN. Looking at the carcinogenicity of human insulin analogues via the intrinsic disorder prism. Scientific Reports. 2016;6(1):23320. PMID: 26983499. 
Available from: 10.1038/srep23320.

69. Jafari S, Babaeipour V, Seyedi HA, Rahaie M, Mofid MR, Haddad L. Recombinant production of mecasermin in E. coli expression system. Research in Pharmaceutical Sciences. 2014;9(6):453-61. PMID: 26339260.

70. Jenkins N. Modifications of therapeutic proteins: challenges and prospects. Cytotechnology. 2007:53(1-3):121-5. PMID: 19003198. Available from: 10.1007/s10616-007-9075-2.

71. Bill RM, Henderson PJ, Iwata S, Kunji ER, Michel H, Neutze R. Overcoming barriers to membrane protein structure determination. Nature Biotechnology. 2011;29(4):335-40. PMID: 21478852. Available from: $10.1038 /$ nbt.1833.

72. Baeshen MN, Al-Hejin AM, Bora RS, Ahmed MM, Ramadan HA, Saini KS. Production of biopharmaceuticals in E. coli: current scenario and future perspectives. Journal of Microbiology and Biotechnology. 2015;25(7):953-62. PMID: 25737124. Available from: $10.4014 /$ jmb.1412.12079.

73. Carrió MM, Villaverde A. Role of molecular chaperones in inclusion body formation. FEBS Letters. 2003;537(1-3):21521. PMID: 12606060 . Available from: $10.1016 /$ S0014-5793(03) 00126- 1.

74. Wildt S, Gerngross TU. The humanization of N-glycosylation pathways in yeast. Nature Reviews Microbiology. 2005;3(2):119-28. PMID: 15685223. Available from: 10.1038/nrmicro1087.

75. Baghban R, Farajnia S, Rajabibazl M, Ghasemi Y, Mafi A, Hoseinpoor R. Yeast expression systems: overview and recent advances. Molecular Biotechnology. 2019;61(5):36584. PMID: 30805909. Available from: 10.1007/s12033-01900164-8.

76. Gerngross TU. Advances in the production of human therapeutic proteins in yeasts and filamentous fungi. $\mathrm{Na}$ ture Biotechnology. 2004;22(11):1409-14. PMID: 15529166. Available from: $10.1038 / \mathrm{nbt} 1028$.

77. Kildegaard J, Buckley ST, Nielsen RH, Povlsen GK, Seested T, Ribel $U$. Elucidating the mechanism of absorption of fastacting insulin aspart: the role of niacinamide. Pharmaceutical Research. 2019;36(3):49. PMID: 30746556. Available from: 10.1007/s11095-019-2578-7.

78. Landgraf W, Sandow J. Recombinant human insulins clinical efficacy and safety in diabetes therapy. European Endocrinology. 2016;12(1):12-7. PMID: 29632581. Available from: 10.17925/EE.2016.12.01.12.

79. Borowicz P, Bocian W, Sitkowski J, Bednarek E, MikiewiczSyguD, Kurzynoga D. Biosynthetic engineered B28(K)B29(P) human insulin monomer structure in water and in water/acetonitrile solutions. Journal of Biomolecular NMR. 2013;55(3):303-9. PMID: 23404086. Available from: 10.1007/ s10858-013-9713-2.

80. Safder I, Khan S, Islam I, Ali M, Bibi Z, Waqas M. Pichia pastoris expression system: a potential candidate to express protein in industrial and biopharmaceutical domains. Biometrical Letters. 2018;4(1):1-14.

81. Polez S, Origi D, Zahariev S, Guarnaccia C, Tisminetzky SG, Skoko N. A simplified and efficient process for insulin production in Pichia pastoris. PLoS One. 2016;11(12):e0167207. PMID: 27907132. Available from: 10.1371/journal.pone. 0167207.

82. Cereghino JL, Cregg JM. Heterologous protein expression in the methylotrophic yeast Pichia pastoris. FEMS Microbiology Reviews. 2000;24(1):45-66. PMID: 10640598. Available from: 10.1111/j.1574-6976.2000.tb00532.x.

83. Tschopp J, Sverlow G, Kosson R, Craig W, Grinna L. Highlevel secretion of glycosylated invertase in the methylotrophic yeast, Pichia pastoris. Nature Biotechnology. 1987;5(12):1305-8. Available from: 10.1038/nbt1287-1305.

84. Schillberg S, Raven N, Spiegel H, Rasche S, Buntru M. Critical analysis of the commercial potential of plants for the production of recombinant proteins. Frontiers in Plant Science. 2019;10:720. PMID: 31244868. Available from: 10.3389/fpls. 2019.00720 .
85. Khan AH, Bayat H, Rajabibazl M, Sabri S, Rahimpour A. Humanizing glycosylation pathways in eukaryotic expression systems. World Journal of Microbiology \& Biotechnology. 2017;33(1):4. PMID: 27837408. Available from: 10.1007/ s11274-016-2172-7.

86. Exposito-Alonso M, Burbano HA, Bossdorf O, Nielsen $R$, Weigel D, Team GFE. Natural selection on the Arabidopsis thaliana genome in present and future climates. Nature. 2019;573(7772):126-9. PMID: 31462776. Available from: 10.1038/s41586-019-1520-9.

87. Tzen JT. Integral proteins in plant oil bodies. International Scholarly Research Notices. 2012;2012:173954. Available from: 10.5402/2012/173954.

88. van Rooijen GJ, Moloney MM. Plant seed oil-bodies as carriers for foreign proteins. Nature Biotechnology. 1995;13(1):72-7. PMID: 9634752. Available from: 10.1038/ nbt0195-72.

89. Damerum A, Chapman MA, Taylor G. Innovative breeding technologies in lettuce for improved post-harvest quality. Postharvest Biology and Technology. 2020;168:111266. PMID: 33012992. Available from: 10.1016/j.postharvbio.2020. 111266.

90. Sun $H$, Sun $X$, Wang $H, M a X$. Advances in salt tolerance molecular mechanism in tobacco plants. Hereditas. 2020;157(1):5. PMID: 32093781. Available from: 10.1186/ s41065-020-00118-0.

91. Boyhan D, Daniell H. Low-cost production of proinsulin in tobacco and lettuce chloroplasts for injectable or oral delivery of functional insulin and C-peptide. Plant Biotechnology Journal. 2011;9(5):585-98. PMID: 21143365. Available from: 10.1111/j.1467-7652.2010.00582.x.

92. Burberry D. Low-cost production of proinsulin in tobacco and lettuce chloroplasts for injectable or oral delivery of functional insulin and C-peptide. Plant Biotechnol J. 2011;9(5):585-98. Available from: 10.1111/j.1467-7652.2010. 00582.x.

93. Baby B, Antony P, Vijayan R. Antioxidant and anticancer properties of berries. Critical Reviews in Food Science and Nutrition. 2018;58(15):2491-507. PMID: 28609132. Available from: 10.1080/10408398.2017.1329198.

94. Dzhanfezova T, Barba-Espín G, Müller R, Joernsgaard $B_{\imath}$ Hegelund JN, Madsen B, et al. Anthocyanin profile, antioxidant activity and total phenolic content of a strawberry (Fragaria $\times$ ananassa Duch) genetic resource collection. Food Bioscience. 2020;36:100620. Available from: 10.1016/j.fbio. 2020.100620

95. Tavizi A, Javaran MJ, Moieni A, Mohammadi-Dehcheshmeh M, Mohebodini M, Ebrahimie E. Root and shoot parts of strawberry: factories for production of functional human pro-insulin. Molecular Biology Reports. 2015;42(5):1013-23. PMID: 25403333. Available from: 10.1007/s11033-014-38377.

96. Dong OX, Ronald PC. Genetic engineering for disease resistance in plants: recent progress and future perspectives. Plant Physiology. 2019;180(1):26-38. PMID: 30867331. Available from: $10.1104 /$ pp.18.01224.

97. Kazmi A, Kazmi A, Shams S, Sajid A, Khan K. Therapeutic role of bone marrow-derived stem cells and zinc sulfate for reduction of liver fibrosis. Progress in Stem Cell. 2019;6(2):269-78. Available from: 10.15419/psc.v6i1.406.

98. Schroeder IS, Rolletschek A, Blyszczuk P, Kania G, Wobus AM. Differentiation of mouse embryonic stem cells to insulinproducing cells. Nature Protocols. 2006;1(2):495-507. PMID: 17406275. Available from: $10.1038 /$ nprot.2006.71.

99. León-Quinto T, Jones J, Skoudy A, Burcin M, Soria B. In vitro directed differentiation of mouse embryonic stem cells into insulin-producing cells. Diabetologia. 2004;47(8):1442-51. PMID: 15309294. Available from: 10.1007/s00125-004-14588.

100. Jiang W, Shi Y, Zhao D, Chen S, Yong J, Zhang J. In vitro derivation of functional insulin-producing cells from human embryonic stem cells. Cell Research. 2007;17(4):333-44. 
PMID: 17426693. Available from: 10.1038/cr.2007.28.

101. Shi Y, Inoue H, Wu JC, Yamanaka S. Induced pluripotent stem cell technology: a decade of progress. Nature Reviews Drug Discovery. 2017;16(2):115-30. PMID: 27980341. Available from: 10.1038/nrd.2016.245.

102. Shahjalal HM, Dayem AA, Lim KM, Jeon TI, Cho SG. Generation of pancreatic $\beta$ cells for treatment of diabetes: advances and challenges. Stem Cell Research \& Therapy. 2018;9(1):355. PMID: 30594258. Available from: 10.1186/s13287-018-10993.

103. Bar-Nur O, Russ HA, Efrat S, Benvenisty N. Epigenetic memory and preferential lineage-specific differentiation in induced pluripotent stem cells derived from human pancreatic islet beta cells. Cell Stem Cell. 2011;9(1):17-23. PMID: 21726830. Available from: 10.1016/j.stem.2011.06.007.

104. Pellegrini S, Ungaro F, Mercalli A, Melzi R, Sebastiani G, Dotta F. Human induced pluripotent stem cells differentiate into insulin-producing cells able to engraft in vivo. Acta Diabetologica. 2015;52(6):1025-35. PMID: 25733399. Available from: 10.1007/s00592-015-0726-z.

105. Huzes GM, Sipos F. Heterogeneity of stem cells: a brief overview. Methods in Molecular Biology. 2016;2016(1516):1-12. PMID: 27044045. Available from: 10.1007/7651_2016_345.

106. Chen Y, Shao JZ, Xiang LX, Dong XJ, Zhang GR. Mesenchymal stem cells: a promising candidate in regenerative medicine. The International Journal of Biochemistry \& Cell Biology. 2008:40(5):815-20. PMID: 18295530. Available from: 10. 1016/j.biocel.2008.01.007.

107. Mundra V, Gerling IC, Mahato RI. Mesenchymal stem cellbased therapy. Molecular Pharmaceutics. 2013;10(1):77-89. PMID: 23215004. Available from: $10.1021 / \mathrm{mp} 3005148$.

108. Bhartiya D. Stem cells to replace or regenerate the diabetic pancreas: huge potential \&amp; existing hurdles. The Indian Journal of Medical Research. 2016;143(3):267-74. PMID: 27241638. Available from: 10.4103/0971-5916.182615.

109. Frenette PS, Pinho S, Lucas D, Scheiermann C. Mesenchymal stem cell: keystone of the hematopoietic stem cell niche and a stepping-stone for regenerative medicine. Annual Review of Immunology. 2013;31 (1):285-316. PMID: 23298209. Available from: 10.1146/annurev-immunol-032712-095919.

110. Bernardo ME, Zaffaroni N, Novara F, Cometa AM, Avanzini MA, Moretta A. Human bone marrow derived mesenchymal stem cells do not undergo transformation after longterm in vitro culture and do not exhibit telomere maintenance mechanisms. Cancer Research. 2007;67(19):9142-9. PMID: 17909019. Available from: 10.1158/0008-5472.CAN06-4690.

111. Negi N, Griffin MD. Effects of mesenchymal stromal cells on regulatory $T$ cells: current understanding and clinical relevance. Stem Cells (Dayton, Ohio). 2020;38(5):596-605. PMID: 31995249. Available from: 10.1002/stem.3151.

112. Düber S, Hafner M, Krey M, Lienenklaus S, Roy B, Hobeika E. Induction of B-cell development in adult mice reveals the ability of bone marrow to produce B-1a cells. Blood. 2009;114(24):4960-7. PMID: 19812384. Available from: 10.1182/blood-2009-04-218156.

113. Hashemian SJ, Kouhnavard M, Nasli-Esfahani E. Mesenchymal stem cells: rising concerns over their application in treatment of type one diabetes mellitus. Journal of diabetes research. 2015;2015:675103. Available from: 10.1155/2015/ 675103.

114. Nemati M, Omrani GR, Ebrahimi B, Alizadeh A. Efficiency of Stem Cell (SC) Differentiation into Insulin-Producing Cells for Treating Diabetes: a Systematic Review. Stem cells international. 2021;2021(2021):6652915. Available from: 10.1155/ 2021/6652915.

115. Lilly MA, Davis MF, Fabie JE, Terhune EB, Gallicano Gl. Current stem cell based therapies in diabetes. American Journal of Stem Cells. 2016;5(3):87-98. PMID: 27853630

116. Solis MA, Velásquez IM, Correa R, Huang LL. Stem cells as a potential therapy for diabetes mellitus: a call-to-action in Latin America. Diabetology \& Metabolic Syndrome. 2019;11(1):20. PMID: 30820250. Available from: 10.1186/ s13098-019-0415-0.

117. Ratajczak MZ, Jadczyk T, Pkedziwiatr D, Wojakowski W. New advances in stem cell research: practical implications for regenerative medicine. Polskie Archiwum Medycyny Wewnetrznej. 2014;124(7-8):417-26. PMID: 24956404. Available from: 10.20452/pamw.2355.

118. Prabakar KR, Domínguez-Bendala J, Molano RD, Pileggi $A$ Villate S, Ricordi C. Generation of glucose-responsive, insulin-producing cells from human umbilical cord bloodderived mesenchymal stem cells. Cell Transplantation. 2012;21(6):1321-39. PMID: 22195604. Available from: 10 . 3727/096368911X612530.

119. Huang CJ, Lin H, Yang X. Industrial production of recombinant therapeutics in Escherichia coli and its recent advancements. Journal of Industrial Microbiology \& Biotechnology. 2012;39(3):383-99. PMID: 22252444. Available from: 10.1007/s10295-011-1082-9.

120. Rosano GL, Ceccarelli EA. Recombinant protein expression in Escherichia coli: advances and challenges. Frontiers in Microbiology. 2014;5:172. PMID: 24860555. Available from: 10.3389/fmicb.2014.00172.

121. Tekarslan-Sahin SH. Metabolic Engineering of Saccharomyces cerevisiae for Industrial Biotechnology, Saccharomyces, Thalita Peixoto Basso and Luiz Carlos Basso, IntechOpen. Available from: 10.5772/intechopen.96030.

122. Karbalaei M, Rezaee SA, Farsiani H. Pichia pastoris: A highly successful expression system for optimal synthesis of heterologous proteins. Journal of Cellular Physiology. 2020;235(9):5867-81. PMID: 32057111. Available from: $10.1002 / j c p .29583$.

123. Wang J, Wang X, Shi L, Qi F, Zhang P, Zhang Y. Methanolindependent protein expression by AOX 1 promoter with trans-acting elements engineering and glucose-glycerolshift induction in Pichia pastoris. Scientific Reports. 2017;7(1):41850. PMID: 28150747. Available from: 10.1038/ srep41850.

124. Ghag SB, Adki VS, Ganapathi TR, Bapat VA. Plant Platform for Efficient Heterologous Protein Production. Biotechnology and Bioprocess Engineering. 2021;2021:1-22. PMID: 34393545.

125. Tremblay R, Wang D, Jevnikar AM, Ma S. Tobacco, a highly efficient green bioreactor for production of therapeutic proteins. Biotechnology Advances. 2010;28(2):214-21. PMID: 19961918. Available from: 10.1016/j.biotechadv.2009.11.008

126. Su H, Yakovlev IA, van Eerde A, Su J, Clarke JL. Plant-Produced Vaccines: Future Applications in Aquaculture. Frontiers in Plant Science. 2021;12:718775. PMID: 34456958. Available from: $10.3389 /$ fpls.2021.718775.

127. McNulty MJ, Kelada K, Paul D, Nandi S, McDonald KA. Introducing uncertainty quantification to techno-economic models of manufacturing field-grown plant-made products. Food and Bioproducts Processing. 2021;128:153-65. Available from: 10.1016/j.fbp.2021.04.013.

128. Castellanos-Morales V, Villegas J, Wendelin S, Vierheilig $\mathrm{H}$, Eder R, Cárdenas-Navarro R. Root colonisation by the arbuscular mycorrhizal fungus Glomus intraradices alters the quality of strawberry fruits (Fragaria $x$ ananassa Duch.) at different nitrogen levels. Journal of the Science of Food and Agriculture. 2010;90(11):1774-82. PMID: 20572056. Available from: 10.1002/jsfa.3998.

129. Kollu L. tem Cell Research-Ethico-Legal Perspectives: Protection of Human Embryos. International Journal of Current Research and Review. 2021;13(7):216-222. Available from: 10.31782/IJCRR.2021.13706.

130. Afify SM, Seno M. Conversion of stem cells to cancer stem cells: undercurrent of cancer initiation. Cancers (Basel). 2019;11(3):345. PMID: 30862050. Available from: 10.3390/ cancers 11030345 . 
131. Beghini DG, Horita SI, Cascabulho CM, Alves LA, HenriquesPons A. Induced pluripotent stem cells: hope in the treatment of diseases, including muscular dystrophies. International Journal of Molecular Sciences. 2020;21(15):5467. PMID: 32751747. Available from: 10.3390/ijms21155467.

132. Lee SH. The advantages and limitations of mesenchymal stem cells in clinical application for treating human diseases. Osteoporosis and Sarcopenia. 2018;4(4):150. PMID: 30775559. Available from: 10.1016/j.afos.2018.11.083.

133. Oggu GS, Sasikumar S, Reddy N, Ella KK, Rao CM, Bokara KK. Gene delivery approaches for mesenchymal stem cell therapy: strategies to increase efficiency and specificity. Stem Cell Reviews and Reports. 2017;13(6):725-40. PMID: 28815481. Available from: 10.1007/s12015-017-9760-2.

134. Eguizabal C, Aran B, de Sousa Lopes SMC, Geens M, Heindryckx B, Panula $S$, et al. Two decades of embryonic stem cells: a historical overview. Human Reproduction Open. 2019;2019(1):hoy024. PMID: 30895264. Available from: 10.1093/hropen/hoy024.

135. Shufaro Y, Reubinoff BE. Therapeutic applications of embryonic stem cells. Best Practice \& Research Clinical Obstetrics \& Gynaecology. 2004;18(6):909-27. PMID: 15582546. Available from: 10.1016/j.bpobgyn.2004.07.002.

136. Yu F, Wei R, Yang J, Liu J, Yang K, Wang H, et al. FoxO1 inhibition promotes differentiation of human embryonic stem cells into insulin producing cells. Experimental cell research. 2018;362(1):227-34. PMID: 29157981. Available from: 10. 1016/j.yexcr.2017.11.022.

137. Rezania A, Bruin JE, Xu J, Narayan K, Fox JK, O'Neil JJ, et al. Enrichment of human embryonic stem cell-derived NKX61-expressing pancreatic progenitor cells accelerates the maturation of insulin-secreting cells in vivo. Stem Cells. 2013;31(11):2432-42. PMID: 23897760. Available from: 10. 1002/stem.1489.

138. Omole AE, Fakoya AOJ. Ten years of progress and promise of induced pluripotent stem cells: historical origins, characteristics, mechanisms, limitations, and potential applications. PeerJ. 2018;6:e4370. PMID: 29770269. Available from: 10.7717/peerj.4370.

139. Hossain MK, Dayem AA, Han J, Saha SK, Yang GM, Choi HY, et al. Recent advances in disease modeling and drug discovery for diabetes mellitus using induced pluripotent stem cells. Int J Mol Sci. 2016;17(2):256. PMID: 26907255. Available from: $10.3390 / \mathrm{ijms} 17020256$.
140. Agrawal A, Narayan G, Gogoi R, Thummer RP. Recent Advances in the Generation of $\beta$-Cells from Induced Pluripotent Stem Cells as a Potential Cure for Diabetes Mellitus. Advances in Experimental Medicine and Biology. 2021;2021. PMID: 34426962. Available from: 10.1007/5584_2021_653.

141. Su Y, Zhang T, Hang T, Gao J. Current advances and challenges of mesenchymal stem cells-based drug delivery system and their improvements. International Journal of Pharmaceutics. 2021;600:120477. PMID: 33737099. Available from: 10.1016/j.ijpharm.2021.120477.

142. Gentile P, Garcovich S. Systematic review: adipose-derived mesenchymal stem cells, platelet-rich plasma and biomaterials as new regenerative strategies in chronic skin wounds and soft tissue defects. International Journal of Molecular Sciences. 2021;22(4):1538. Available from: 10.3390/ ijms22041538.

143. Qi Y, Ma J, Li S, Liu W. Applicability of adipose-derived mesenchymal stem cells in treatment of patients with type 2 diabetes. Stem Cell Research and Therapy. 2019;10(1):274 PMID: 31455405. Available from: 10.1186/s13287-019-13622.

144. Kadam S, Muthyala S, Nair P, Bhonde R. Human placentaderived mesenchymal stem cells and islet-like cell clusters generated from these cells as a novel source for stem cell therapy in diabetes. Rev Diabet Stud. 2010;7(2):168-82. PMID: 21060975. Available from: 10.1900/RDS.2010.7.168.

145. Feng $X$, Liu J, Xu Y, Zhu J, Chen W, Feng B, et al. Molecular mechanism underlying the difference in proliferation between placenta-derived and umbilical cord-derived mesenchymal stem cells. Journal of Cellular Physiology. 2020;235(10):6779-6793. PMID: 31990045. Available from: $10.1002 /$ jcp. 29572.

146. Accomasso L, Gallina C, Turinetto V, Giachino C. Stem cell tracking with nanoparticles for regenerative medicine purposes: an overview. Stem Cells International. 2016;2016:7920358. PMID: 26839568. Available from: 10 . $1155 / 2016 / 7920358$.

147. Nagamura-Inoue T, He H. Umbilical cord-derived mesenchymal stem cells: their advantages and potential clinical utility. World journal of stem cells. 2014;6(2):195-202. PMID: 24772246. Available from: 10.4252/wjsc.v6.i2.195.

148. Fan CG, j Zhang Q, r Zhou J. Therapeutic potentials of mesenchymal stem cells derived from human umbilical cord. Stem Cell Reviews and Reports. 2011;7(1):195-207. PMID: 20676943. Available from: 10.1007/s12015-010-9168-8. 
Ready to submit your manuscript? Choose Biomedpress and benefit from:

- Fast, convenient online submission

- Through peer-review by experienced researchers

- Rapid publication on acceptance

- Free of charge (without publication fees)

Learn more http://www.biomedpress.org/journals/

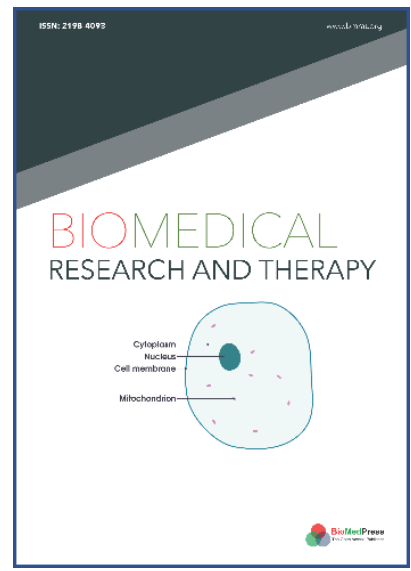

\title{
Biomedical Research and Therapy
}

Indexed: Web of Science (ESCl), Embase, Google Scholar

Journal Citation Indicator (2020): 0.16

Acceptance Rate (2020): 54.32\%

Article Publishing Charge: Free

Submission to first editorial decision: 27 days

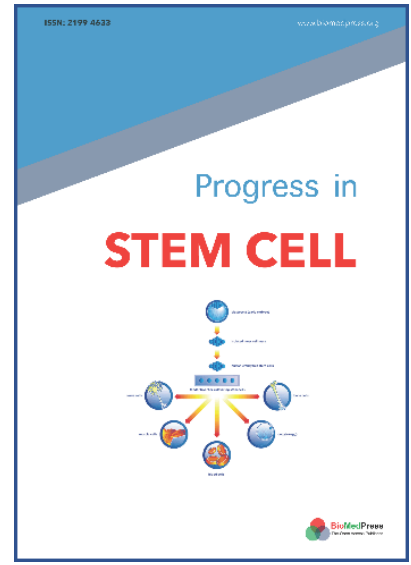

\section{Progress in Stem Cell}

Indexed: Embase, Google Scholar

Acceptance Rate (2020): 78.19\%

Article Publishing Charge: Free

Submission to first editorial decision: 19 days

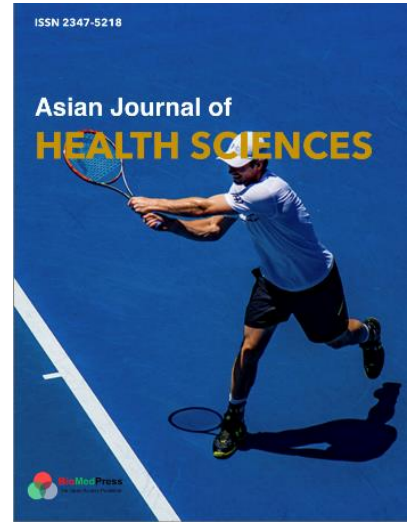

\author{
Asian Journal of Health Sciences \\ Indexed: Google Scholar \\ Acceptance Rate (2020): 72.89\% \\ Article Publishing Charge: Free \\ Submission to first editorial decision: 16.5 days
}

